\title{
High-Frequency Radar Observations of Surface Circulation Features along the South-Western Australian Coast
}

\author{
Simone Cosoli *, Charitha Pattiaratchi ${ }^{(D)}$ and Yasha Hetzel $\mathbb{D}$ \\ Ocean Graduate School and the UWA Oceans Institute, The University of Western Australia, 35 Stirling \\ Highway, Perth, WA 6009, Australia; chari.pattiaratchi@uwa.edu.au (C.P.); yasha.hetzel@uwa.edu.au (Y.H.) \\ * Correspondence: simone.cosoli@uwa.edu.au; Tel.: +61-8-6488-7314
}

Received: 10 January 2020; Accepted: 4 February 2020; Published: 5 February 2020

\begin{abstract}
A new merged high-frequency radar (HFR) data set collected using SeaSonde and WERA (WEllen RAdar) systems was used to examine the ocean surface circulation at diurnal, seasonal and inter-annual time scales along the south-west coast of Australia (SWWA), between $29^{\circ}-32^{\circ} \mathrm{S}$. Merging was performed after resampling WERA data on the coarser SeaSonde HFR grid and averaging data from the two HFR systems in the area of common overlap. Direct comparisons between WERA and SeaSonde vectors in their overlapping areas provided scalar and vector correlation values in the range $\mathrm{Ru}=[0.24,0.76] ; \mathrm{Rv}=[0.39,0.83] ; \rho=[0.44,0.75]$, with mean bias between velocity components in the range $[-0.02,0.28] \mathrm{ms}^{-1},[-0.16,0.16] \mathrm{ms}^{-1}$ for the $\mathrm{U}, \mathrm{V}$ components, respectively. The lower agreement between vectors was obtained in general at the boundaries of the HFR domains, where the combined effects of the bearing errors, geometrical constraints, and the limited angular field of view were predominant. The combined data set allowed for a novel characterization of the dominant features in the region, such as the warmer poleward-flowing Leeuwin Current (LC), the colder Capes Current (CC) and its northward extensions, the presence of sub-mesoscale to mesoscale eddies and their generation and aggregation areas, along with the extent offshore of the inertial-diurnal signal. The contribution of tides was weak within the entire HFR domain $(<10 \%$ total variance), whilst signatures of significant inertial- and diurnal-period currents were present due to diurnal-inertial resonance. A clear discontinuity in energy and variance distribution occurred at the shelf break, which separates the continental shelf and deeper offshore regions, and defined the core of the LC. Confined between the LC and the coastline, the narrower and colder CC current was a feature during the summer months. Persistent (lifespan greater than 1 day) sub-mesoscale eddies (Rossby number $\mathrm{O}(1)$ ) were observed at two main regions, north and south of $31.5^{\circ} \mathrm{S}$, offshore of the $200 \mathrm{~m}$ depth contour. The majority of these eddies had diameters in the range 10-20 km with 50\% more counter clockwise rotating (CCW) eddies compared to clockwise (CW) rotating eddies. The northern region was dominated by CCW eddies that were present throughout the year whilst $\mathrm{CW}$ eddies were prevalent in the south with lower numbers during the summer months.
\end{abstract}

Keywords: high frequency radar; sea surface temperature; surface currents; south-west Australia

\section{Introduction}

Surface circulation along the eastern margin the southern Indian Ocean is very different compared to other ocean basins, with the poleward Leeuwin Current (LC) transporting warmer water (Figure 1) and promoting a downwelling system [1]. The eastern margins of all other ocean basins comprise equatorward cold water currents associated with upwelling. The anomalous ocean currents together with diurnal tides with low range [2], strong sea breezes [3], resonance at the critical latitude [4], 
high air-sea heat and freshwater fluxes [5] provide a unique environment. In addition, the LC is associated with elevated levels of mesoscale eddy activity compared with other eastern boundary current regions [6,7]. The region is dominated by two major currents (Figure 1): the warmer Leeuwin Current (LC), flowing southwards along the shelf break, and the colder Capes Current (CC), flowing northwards along the continental shelf inshore the LC $[1,8]$.

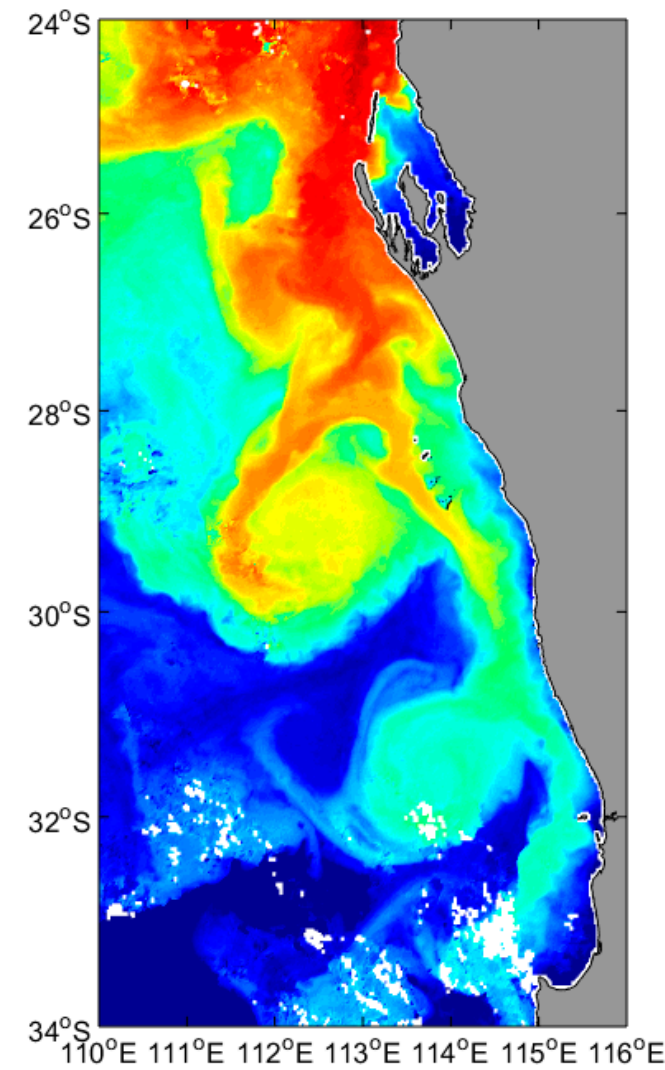

(a)

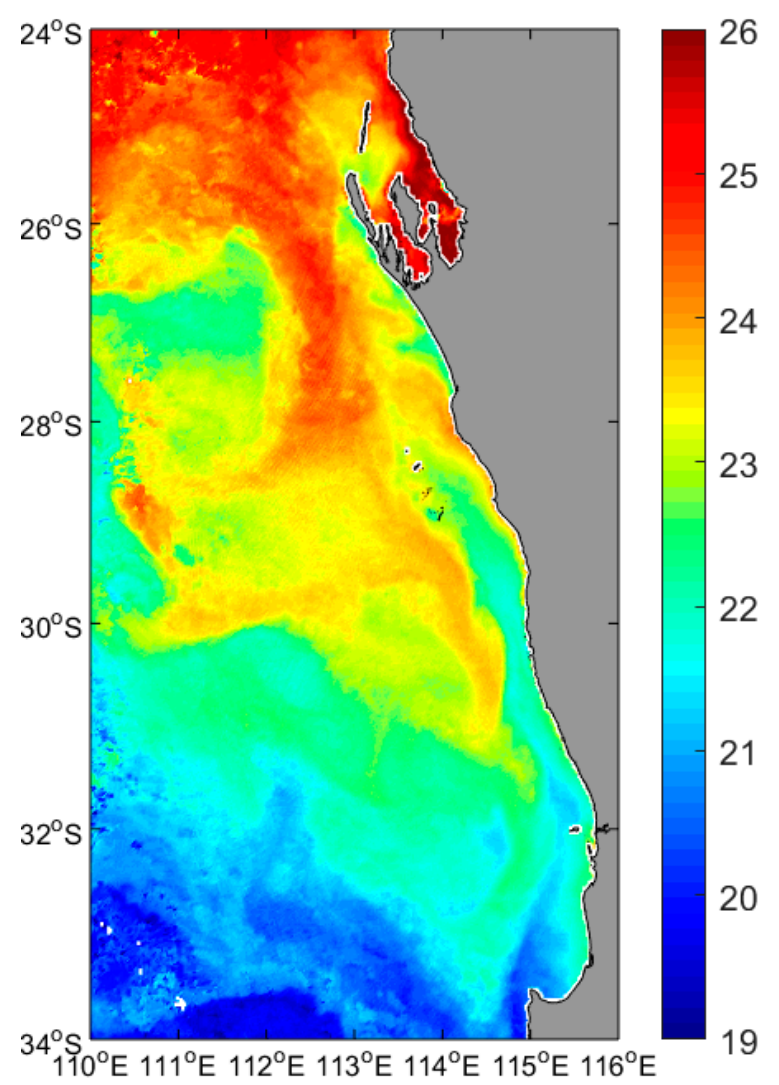

(b)

Figure 1. Satellite derived sea surface temperature distribution $\left({ }^{\circ} \mathrm{C}\right)$ during: (a) winter (28 May 2018); and, (b) summer (23 February 2016) indicating the eddy systems of the Leeuwin Current (LC) and colder Capes Current (CC). Sea surface temperature (SST) data originated from the multi-sensor Australian Integrated Marine Observing System (IMOS) L3S foundation SST product.

The LC is a poleward eastern boundary current driven by an alongshore pressure gradient, generated through the transport of warmer, lower salinity water into the tropical Indian Ocean by the Indonesian Throughflow [9-11]. It is augmented with contributions from the central South Indian Counter Current (SICC) and the Holloway Current in the shelf region around $20^{\circ}-23^{\circ} \mathrm{S}$ and from southern SICC at around $32^{\circ} \mathrm{S}$. LC flows southwards as a relatively narrow ( $100 \mathrm{~km}$ wide), shallow (upper $250 \mathrm{~m}$ ) current along the continental shelf break ( 200 m) to the southern tip of Tasmania [11,12]. The LC has a seasonal pattern with intensification during Austral autumn/winter (April-September) and a weakening during the Austral summer months (November-March). This seasonal variability is controlled by seasonal changes in the wind stress: (1) during the Australasian monsoon season (January to March) to the north of Australia [13]; and, (2) equatorward wind stress within the study region [3,9]. The LC is also influenced by El Niño and La Niña cycles with the current being stronger (weaker) during La Niña (El Niño) events due to fluctuations in the ITF and equatorial monsoonal winds $[10,11,14]$. Typical features of the LC include meanders, eddies, and filaments [15] and are highlighted in Figure 1. One of the major features of the LC is the presence of a highly energetic meso-scale eddy field with diameters $>200 \mathrm{~km}$ and lifetimes of one month or more [15-18]. Anti-clockwise (warm-core) and 
clockwise (cold-core) rings are generated by the LC at preferential locations (Figure 1) that are associated with changes in the coastline orientation, and they migrate westward into the interior of the southern Indian Ocean [6]. The formation of these eddies has been postulated to be from different mechanisms such as instabilities through meanders, shear between the LC and Leeuwin Undercurrent/Capes Current and bathymetric features [16-19] and are located at $\sim 28^{\circ} \mathrm{S}$ and $\sim 30.5^{\circ} \mathrm{S}$ (Figure 1). These eddies are important circulation features, as they influence the heat and momentum balance [7]; regional upwelling and therefore contribute to local biological activity $[16,19,20]$ and, influence the coastal wave climate [21].

The CC is a wind driven current that transport upwelled cooler, salty waters northwards inshore of the LC (Figure $1 \mathrm{~b}$ ) originating at $\sim 34^{\circ} \mathrm{S}$ and extending as far north as $29^{\circ} \mathrm{S}$ [8]. It is mainly present during the summer months (November-March) when the upwelling favorable equatorward winds are the strongest. Here, due to Ekman dynamics, the upper layers move offshore in response to the northward wind stress pushing the LC offshore $[7,8]$. The CC is usually visible as a band of colder water on the continental shelf (Figure 1b).

Wind action is the primary driving mechanism for surface current variability on the continental shelf. The study region is micro-tidal, dominated by diurnal tides and with a mean spring tidal range of $\pm 0.6 \mathrm{~m}$ [2]. The inertial period is around $24 \mathrm{~h}$. The strong land-sea breeze (LSB) regime that characterizes this region $[3,4,22]$ results in strong counterclockwise diurnal currents in the upper-ocean dynamics through the diurnal-inertial resonance at critical latitudes, that can penetrate below the mixed-layer depth [4]. Extra-tropical storms or tropical cyclones may also contribute to the intensification of upper layer current variability in the region [23].

The study region consists of several distinct bathymetric features (Figure 2): (1) an upper continental shelf terrace to a depth of $100 \mathrm{~m}$; (2) rapid increase in water depth between the 100 and $200 \mathrm{~m}$ depth contours; (3) the main shelf break at the $200 \mathrm{~m}$ isobath; and, (4) presence of the Perth canyon at $32^{\circ} \mathrm{S}$ with maximum depths to $4000 \mathrm{~m}$.

High-frequency radar (HFR) measurement of surface currents in the coastal ocean has become a standard and cost-effective component for ocean observing systems globally [24]. They were developed more than three decades ago $[25,26]$ and are now widely used with a high level of accuracy $[27,28]$ for a variety of purposes, including ocean current forecasting [29] and long-term trends in surface circulation in coastal areas [30]. HFR systems allow for the synoptic observation of large-scale coastal circulation features with temporal and spatial resolution not readily available with conventional instrumentation a high level of accuracy [27]. As part of the Australian Integrated Marine Observing System (IMOS), HFR systems have been deployed along the south-west Australian coast since 2009.

Previous studies in the region have mainly used satellite imagery $[6,8,15]$, shipborne measurements [1,7,31] and, numerical modelling [17,19]. Mihanovic et al. [4] used oceanographic moorings, satellite sea surface temperature (SST) and HFR data in the southern section of the study region to examine the diurnal-inertial resonance at the critical latitude during the summer months. Studies that have examined the diurnal, seasonal and eddy dynamics in the study region have been limited either by low spatial and temporal resolution (e.g., satellite data), or restricted by small spatial domains (e.g., moorings or single HFR systems).

We build on previous work by merging data from two HFR systems that doubles the spatial coverage whilst retaining the high temporal and spatial information. The aim of this paper is to describe the surface oceanographic features along the coast of south-west Western Australia (SWWA) using the new merged near-surface HFR derived currents. The emphasis is on characterising the: (1) surface currents at diurnal (including inertial) lower frequency ( $>4$ days) and seasonal time scales; and, (2) dynamics of the eddy field. The merged surface current data were collected over a 33-month period (January 2015 to September 2017) and covered a region $180 \mathrm{~km}$ offshore and $250 \mathrm{~km}$ alongshore at a resolution of $6 \mathrm{~km}$.

This paper is arranged as follows: Section 2 describes the data collection and analysis techniques. Results and discussion are presented in Sections 3 and 4. The conclusions are presented in Section 5. 


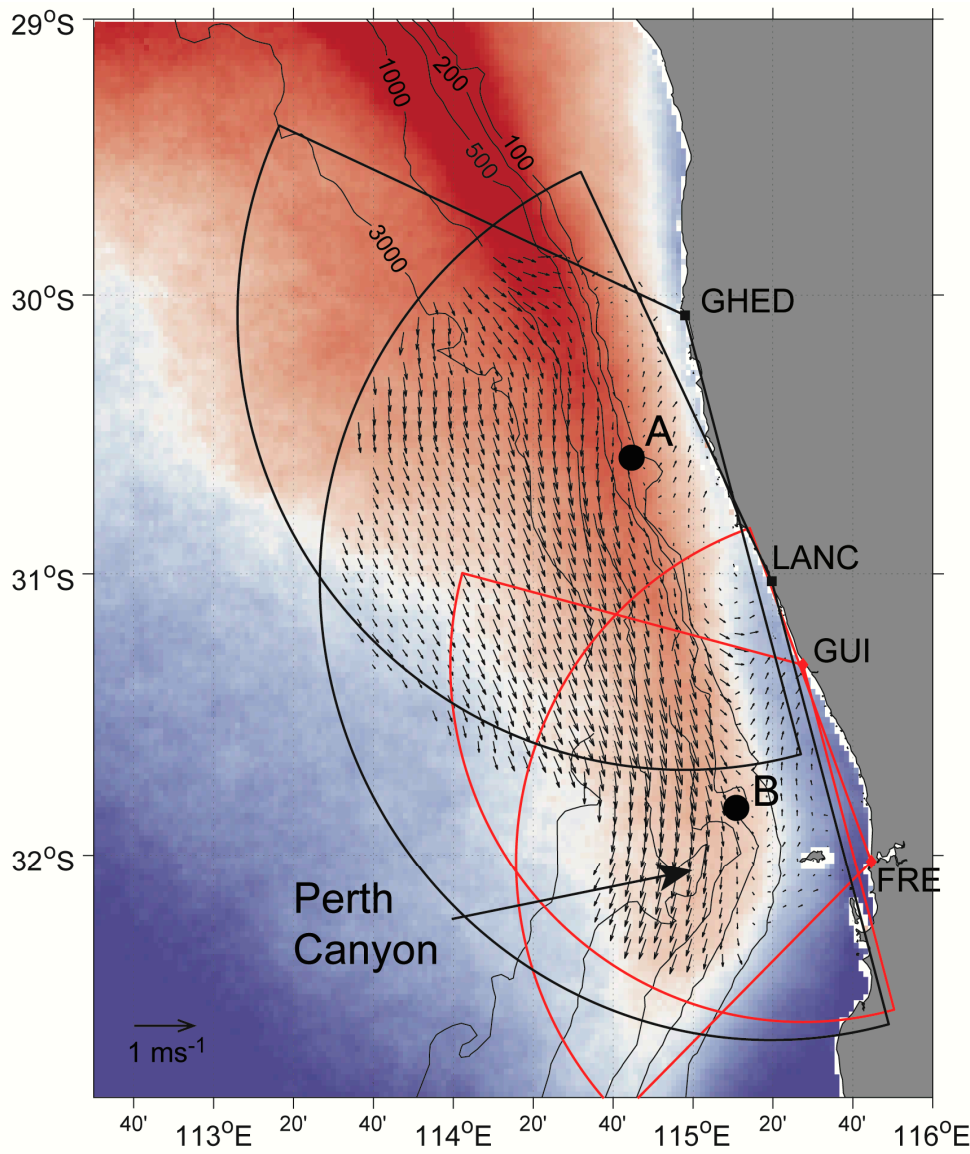

Figure 2. The study region showing the high-frequency radar (HFR) coverage region. Locations marked A and B correspond to the points with maximum data return for the Seasonde (A) and WERA (B) HFR nodes, respectively. The time averaged HFR currents are overlain on SST data for the period January 2015-September 2017.

\section{Materials and Methods}

Surface current data (top $2 \mathrm{~m}$ of the water column) collected by long-range HFR systems (Figure 2) over the 33-month period January 2015 to September 2017 were used in this study. HFR current data were sourced through commercial direction-finding (SeaSonde) and phased-array (WERA) HFR systems, provided by Codar Ocean Sensors (COS) and Helzel MessTechnik, respectively.

Two SeaSonde systems, located at Lancelin (LANC; $31^{\circ} 01.588^{\prime}$ S, $115^{\circ} 19.708^{\prime}$ E) and Green Head (GHED; $30^{\circ} 04.393^{\prime} \mathrm{S}, 114^{\circ} 58.003^{\prime} \mathrm{E}$ ), were used to collect ocean currents at hourly intervals with ranges up to $200 \mathrm{~km}$ offshore with a spatial resolution of $6 \mathrm{~km}$. Both stations operated at a central frequency of $4.463 \mathrm{MHz}$ (measurement depth is approximately $2.5 \mathrm{~m}$ ) with a $25 \mathrm{kHz}$ bandwidth, 512-point fft, $1 \mathrm{~Hz}$ sweep rate, $20 \mathrm{~min}$ Doppler spectra averaging with 15-min output rate. Calibrated antenna patterns are used at both stations. Two WERA systems, located at Guilderton (GUI; 31 $20.4960^{\prime}$ S, $115^{\circ} 29.3640^{\prime}$ E) and Port Beach, Fremantle (FRE; 32 $.0198^{\prime}$ S, $115^{\circ} 44.7480^{\prime}$ E) provided hourly ocean surface currents at ranges up to $180 \mathrm{~km}$ offshore at $4 \mathrm{~km}$ spatial resolution. Both sites used 4-element transmit and receive arrays of 16 equally spaced elements. Systems operated at $9.335 \mathrm{MHz}$ (sampling depth approximately $1.3 \mathrm{~m}$ ) with $33.3 \mathrm{kHz}$ bandwidth, 1024-point fft and $0.26 \mathrm{~s}$ sweep rate, and an integration time of $5 \mathrm{~min}$. Radial velocity data were collected on a Cartesian grid with $4 \mathrm{~km}$ spacing every $10 \mathrm{~min}$ in alternate mode. The same Cartesian grid was used to compute hourly surface current vectors from the hourly-averaged radial data.

Sea-surface temperature (SST) data originate from quality-controlled, merged, day and night, multi-sensor L3S foundation SST product from IMOS level L3S gridded single-sensor composites 
(IMOS-SRS SATELLITE-SST L3S-01 day composite). SST data for the WA coast were downloaded from the AODN (Australian Ocean Data Network) data portal (https://portal.aodn.org.au). HRPT AVHRR (High Resolution Picture Transmission/Advanced Very High Resolution Radiometer) SST (sea surface temperature) retrievals are produced by the Australian Bureau of Meteorology as a contribution to the Integrated Marine Observing System [32].

The analysis approach used hourly, daily, monthly and seasonally-averaged delayed-mode quality controlled (DMqc) data [33], and the most appropriate statistical tools were used to characterize the dominant circulation features in the study region.

Smoothed estimates of the power density distribution (PSD) of surface HFR currents were derived from hourly HFR data in order to partition current variance over resolvable frequencies at each HFR grid cell. Spectra of hourly HFR observations were derived following the Welch-modified periodogram method [34] using 1024-point segments (approximately 42-days long segments), a Hanning window and $50 \%$ overlap between the data segments. Band-averaged energy levels were then extracted by integrating the resulting PSD curves in the selected frequency bands: diurnal-inertial frequency [0.038, 0.046] cph (cycles per hour), corresponding to periods in the range [ $21 \mathrm{~h} 44 \mathrm{~m} 20.8 \mathrm{~s}, 26 \mathrm{~h} 18 \mathrm{~m}$ $56.8 \mathrm{~s}$; ; and, low-frequency band, with frequency $<0.0088 \mathrm{cph}$, or periods longer than $4 d$. Rotary coefficients $\left(C_{R}\right.$; Equation (1); [35]), were then derived from the smooth PSD estimates of the clockwise $(\mathrm{CW})$ - counterclockwise (CCW) spectra:

$$
C_{R}=\frac{P S D_{+}(\omega)-P S D_{-}(\omega)}{P S D_{+}(\omega)+P S D_{-}(\omega)}
$$

where $P S D_{ \pm}(\omega)$ are, the CCW and CW spectral estimates at each HFR grid cell at the frequency $\omega$ respectively. $C_{R}$ quantifies the degree of polarization of current observations at each frequency band; for purely rectilinear flow, $C_{R}$ equals to zero, and $C_{R}= \pm 1$ for purely circular (counterclockwise-clockwise) motion.

The MATLAB $t$ tide package [36] was used to quantify the contribution of tidal forcing to the current variance. Synthetic time series at each grid cell included in the analysis are derived using only constituents with signal-to-noise ratios greater than 2.

For spectral analysis, gaps in the time series were linearly interpolated before the fft calculations, whilst no interpolation was performed before the tidal analyses. Grid points with at least $70 \%$ data return were used for both analyses, in order to increase the frequency resolution and reduce biases from missing data.

The merged SeaSonde-WERA data set was obtained as follows. DMqc procedures described in $[33,37]$ were applied separately to SeaSonde and WERA current vector data at each HFR grid point. DMqc flags were applied to the hourly data sets to exclude anomalous currents from the records. We then computed daily-averaged currents fields separately for the SeaSonde and WERA HFR data sets using grid points with at least 50\% data return (after removing spikes). Daily SeaSonde and WERA currents were remapped on a common longitude-latitude grid by searching velocity data within $2 \mathrm{~km}$ from each grid cell, and averaging separately the $U, V$ components of the velocity vectors. In case of overlap between SeaSonde and WERA currents, U, V from both HFR genres were averaged.

Validation of SeaSonde and WERA HFR data in the region against current meter data for the same data period were performed previously [33,38], showing that both HFR types captured the variability sampled by the current meters consistent with accuracy levels reported in the literature. The interoperability of the two HFR genres in the region was also demonstrated for a shorter time period (1 month), showing that radial data from SeaSonde can be merged successfully with radial data from WERA systems with no significant performance losses [38]. Extending the comparisons to the overlapping areas between the two grids, scalar (vector [39]) correlation (Equation (2); Equation (4)) values for the $\mathrm{U}, \mathrm{V}$ components were in the range $\mathrm{Ru}=[0.24,0.76] ; \mathrm{Rv}=[0.39,0.83] ; \rho=[0.44,0.75]$ : 


$$
\begin{gathered}
R=\frac{\sum_{i=1}^{n}\left(x_{i}-\bar{x}\right)\left(y_{i}-\bar{y}\right)}{(n-1) \sigma_{x} \sigma_{y}} \\
\sigma_{x}=\sqrt{\frac{\sum_{i=1}^{n}\left(x_{i}-\bar{x}\right)^{2}}{n-1}} \\
\rho=\frac{u_{1} u_{2}+v_{1} v_{2}+i u_{1} v_{2}-v_{1} u_{2}}{u_{1}^{2}+v_{1}^{21 / 2} u_{2}^{2}+v_{2}^{21 / 2}} \\
\text { bias }=\frac{\sum_{i=1}^{n}\left(x_{i}-y_{i}\right)}{n}
\end{gathered}
$$

In Equations (4), $\left(u_{1,2}, v_{1,2}\right)$ stand for the zonal and meridional components of the SeaSonde (WERA) HFR velocity components respectively, $i$ identifies the imaginary unit, and $<>$ represents the ensemble average operator.

Values for $\mathrm{U}, \mathrm{V}$ biases (Equation (4)) were in the range bias $\mathrm{U}=[-0.02,0.28] \mathrm{ms}^{-1}$, bias $_{\mathrm{V}}=[-0.16$, $0.16] \mathrm{ms}^{-1}$. Statistics reported here are relative to a sample of 67 grid points, with a lowest population (number of common data) in excess of 500. It must be pointed out that lower agreement between vectors was obtained in general at the boundaries of the SeaSonde domain, where the combined effects of the bearing errors [33,38], the geometrical constraints common to both systems, and the limited angular field of view of the WERA systems were predominant.

For the following analyses, the HFR and SST data were seasonally averaged for 2015, 2016 and 2017. Here, the seasons were defined as: austral summer: December, January, February (DJF); autumn: March, April, May (MAM); winter: June, July, August (JJA); spring: September, October, November (SON). The daily-, monthly-, and seasonally-, averaged, merged SeaSonde-WERA HFR currents were then used for detailed analysis.

Ocean motions can be divided into four classes based on horizontal length scales [40]: (1) large scale motions that are $>300 \mathrm{~km}$; (2) meso-scale motions are related to eddies with diameters $50-300 \mathrm{~km}$; (3) sub-mesoscale motions have horizontal scales 1-50 km; and, (4) small-scale motions have scales $<1 \mathrm{~km}$. With HFR coverage, extending 100-170 km offshore with a resolution of $6 \mathrm{~km}$, only sub-mesoscale motions could be resolved. Statistics of eddies (lifespan, dimensions, locations, rotation sense, vorticity, eddy Rossby number) were extracted from the daily-averaged, merged SeaSonde-WERA data set. The vector geometry approach described in [41] was used to identify eddies and their properties in the merged data set. Sub-mesoscale eddies that have time scales of $\mathrm{O}$ (days) are commonly observed in the region, particularly in the shear region between the LC and the CC currents, and only persistent eddies (minimum lifespan 1 day) could be detected in the data set used here.

Relative vorticity $\left(\zeta_{\mathrm{HF}}\right.$; Equation (6)), divergence $\left(\omega_{\mathrm{HF}}\right.$; Equation $\left.(7)\right)$ and Rossby number $\left(\mathrm{R}_{\mathrm{o}}\right.$; Equation (8)) were computed from the merged, daily-averaged HFR currents at each grid point by a locally least-squares fitting a velocity plane to each grid point using current measurements from nearby locations [42]. Planetary vorticity $(f)$ is defined in Equation (9), with $\Omega=7.2921 \times 10^{-5}$ radians/s the rotation rate of Earth and $\theta$ the latitude.

$$
\begin{gathered}
\zeta_{H F}=\frac{\partial v}{\partial x}-\frac{\partial u}{\partial y} \\
\omega_{H F}=\frac{\partial u}{\partial x}+\frac{\partial v}{\partial y} \\
R o=\frac{\zeta_{H F}}{f} \\
f=2 \Omega \sin \theta
\end{gathered}
$$




\section{Results}

\subsection{The Mean State}

The mean HFR currents over the study period (January 2015 to September 2017) indicated southward currents, offshore the $200 \mathrm{~m}$ contour over the whole HFR coverage region associated with warmer SSTs (Figure 2). This is the Leeuwin Current. In the northern region of HFR coverage, the range of the SeaSonde system extended further offshore compared to the southern region where the range of WERA was lower. Inshore of the $100 \mathrm{~m}$ depth contour, the currents were variable but the majority contained a northward component and were associated with colder water, particularly in the southern region of HFR coverage (Figure 2). This is the signature of the wind-driven Capes Current, most prominent during the summer months. There was also a northward component of wind stress, during the winter months that resulted in northward currents.

The mean cross-shelf profile of HFR currents and SST both indicated a Gaussian shape with weaker currents inshore, increasing to a maximum (the LC 'core') and then decreasing further offshore (Figure 3). The SST profiles indicated colder water inshore, increasing offshore to a maximum and then decreasing further offshore (Figure 3b). The peak in the southward velocity maxima was located further offshore compared to the SST maxima. For example, at $31^{\circ} \mathrm{S}$, the peak in velocity $\left(-0.17 \mathrm{~ms}^{-1}\right)$ was located at $114.5^{\circ} \mathrm{E}$ whilst for SST it was at $114.8^{\circ} \mathrm{E}$ (Figure 3). The LC flows parallel the depth contours (Figure 2). However, the depth contours (and the shoreline) is oriented $337^{\circ}$ with respect to north. Therefore, the $200 \mathrm{~m}$ depth contour is shifted to the east as we move south. This is reflected in the cross-shelf profiles of both HFR currents and SST with the maxima migrating eastward (Figure 3). Profiles of HFR currents also indicated northward mean currents at the two southern latitudes $\left(0.07 \mathrm{~ms}^{-1}\right.$ at $32^{\circ} \mathrm{S}$ and $0.025 \mathrm{~ms}^{-1}$ at $\left.31.7^{\circ} \mathrm{S}\right)$ whist at $31^{\circ} \mathrm{S}$, although the currents so not indicate a positive component mean currents were close to zero $\left(-0.02 \mathrm{~ms}^{-1}\right)$. The maximum velocity of the LC 'core' increased southward, from $-0.17 \mathrm{~ms}^{-1}$ at $31^{\circ} \mathrm{S}$ and $31.7^{\circ} \mathrm{S}$ to $-0.22 \mathrm{~ms}^{-1}$ at $32^{\circ} \mathrm{S}$ (Figure 3a). In contrast, the SST maximum decreased from $21.35^{\circ} \mathrm{C}$ to $21.06{ }^{\circ} \mathrm{C}$ at $31^{\circ} \mathrm{S}$ (Figure $3 \mathrm{~b}$ ).
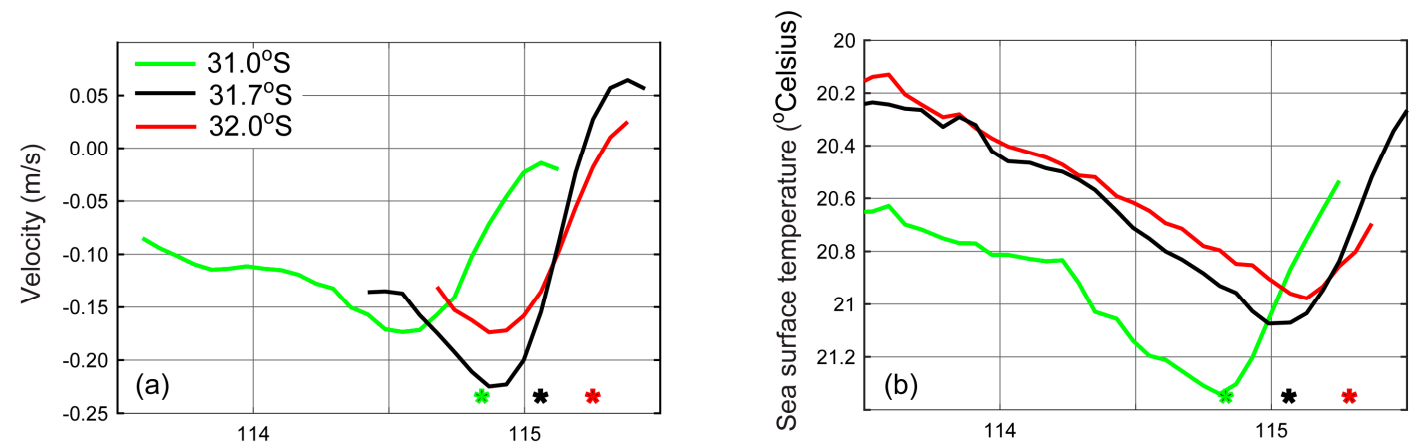

Figure 3. Mean cross-shelf profiles of (a) velocity; and, (b) sea surface temperature at different latitudes. The asterisk denotes the location of the $200 \mathrm{~m}$ depth contour. Units for the $x$-axis are ${ }^{\circ} \mathrm{E}$.

\subsection{Seasonal and Inter-Annual Variability}

Seasonally averaged HFR and SST data indicated the typical mean circulation structures in the region with the relatively warmer LC as a southward current and the CC as a weaker, colder coastal current (Figures 4-6). The presence of colder water adjacent to the coast during the autumn and winter months (Figures 4c, 5c and 6c) is due to heat loss [5]. In general, the LC was stronger (mean speeds up to $0.50 \mathrm{~ms}^{-1}$ ), during autumn/winter and weaker during spring/summer.

During the summer months, a band of colder water associated with northward currents is the CC (Figures 4a, 5a and 6a). Note that the water adjacent the shoreline is warmer due to summer solar heating and the band of colder water, associated with the upwelling CC, is located further offshore but inshore of the warmer LC. The boundary between the colder and warmer water corresponded with a 
change in current direction from northward to southward with strong horizontal velocity gradients. This was also highlighted by the cross-shelf velocity profiles at different latitudes where northward (positive) current component were recorded inshore (Figure 7a). At $31.0^{\circ} \mathrm{S}$, the LC was present as a broader current with the strongest currents west of $114.5^{\circ} \mathrm{E}$ whilst at $31.7^{\circ} \mathrm{S}$ and $32.0^{\circ} \mathrm{S}$ the cross-shelf profiles indicated positive and negative maxima associated with the LC and CC (Figure 7a).
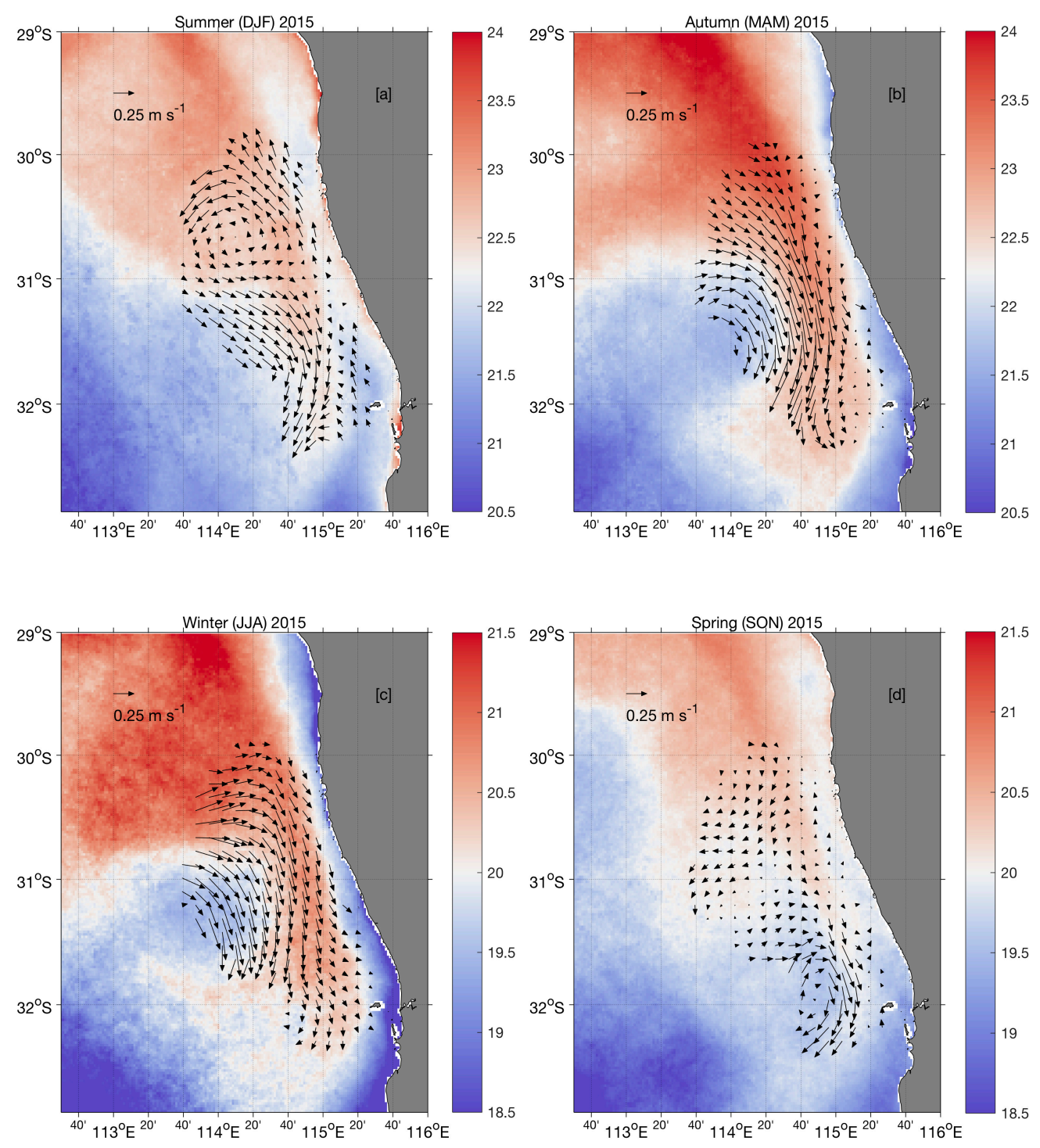

Figure 4. Seasonally-averaged HFR and SST data for 2015: (a) Summer (DJF); (b) Autumn (MAM); (c) Winter (JJA); (d) Spring (SON). Note changes in SST scale for summer/autumn (a,b) and winter/spring $(\mathbf{c}, \mathbf{d})$. Vector data have been subsampled every two grid point to increase readability. SST data originated from multi-sensor L3S foundation SST product.

During the winter months, the LC was the most dominant feature mostly associated with the warmer water. Although the HFR coverage captured the 'core' of the current, the larger meso-scale eddies were not captured fully. For example, in 2015, there was a large mesoscale clockwise eddy centered around $31.5^{\circ} \mathrm{S}, 114.0^{\circ} \mathrm{E}$ during autumn and winter that was only captured partially (Figure $4 b, c$ ) although altimetry data indicated the presence (and the persistence) of this eddy through autumn to winter (http://oceancurrent.imos.org.au/). Similar partial capture of a clockwise mesoscale eddy was also recorded during winter months of 2016 and 2017 (Figures 5c and 6c). Cross-shelf velocity profiles at different latitudes indicated strengthening of the southward (negative) current component, compared to those during the summer at all three latitudes (Figure 7). In particular, 
at $31.0^{\circ} \mathrm{S}$, there was a pronounced 'core' in the LC with a maximum at $114.6^{\circ} \mathrm{E}$, a significant onshore migration during winter compared to the summer (see Figure $7 \mathrm{a}, \mathrm{b}$ ).
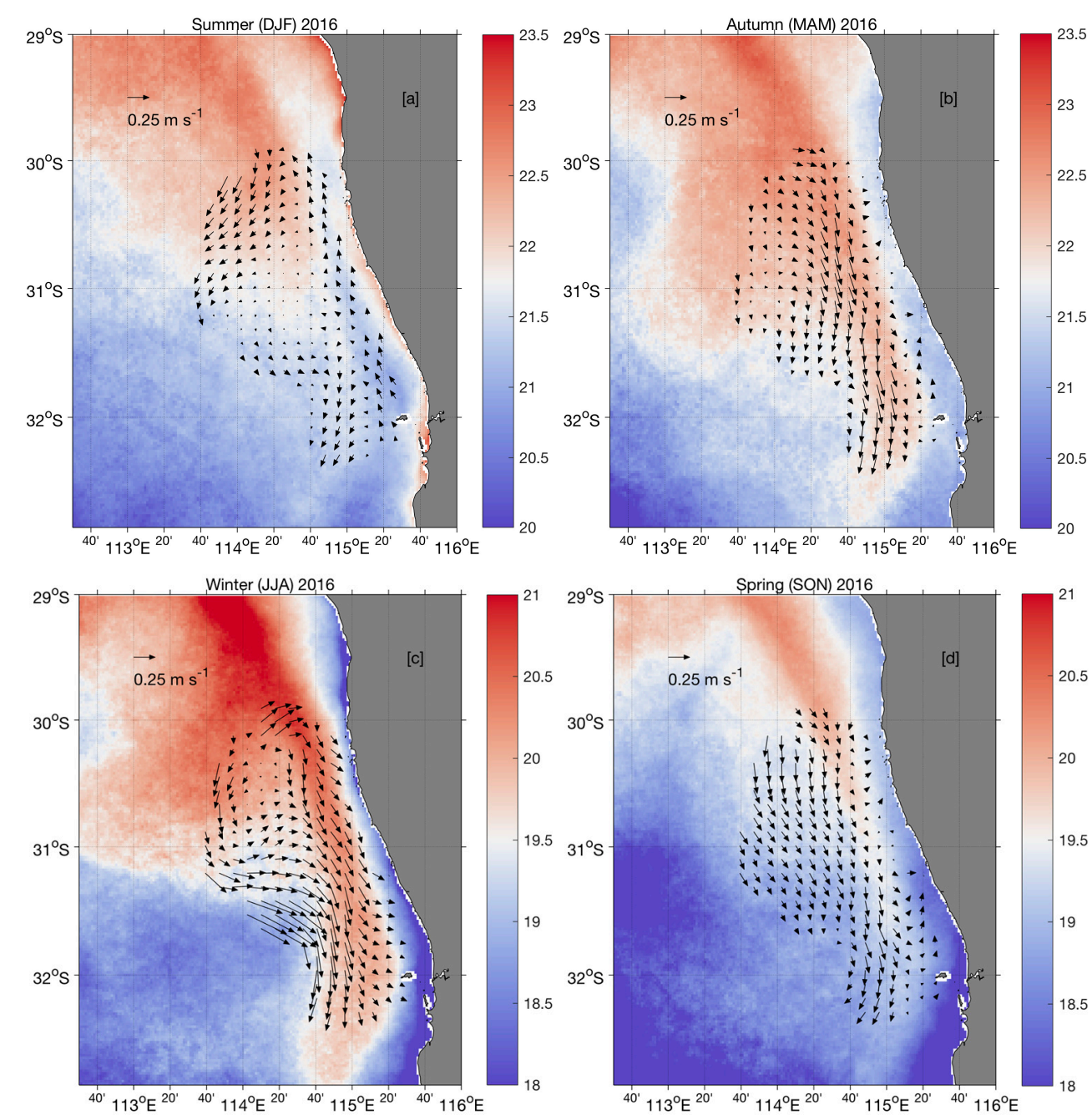

Figure 5. Seasonally-averaged HFR and SST data for 2016: (a) Summer (DJF); (b) Autumn (MAM); (c) Winter (JJA); (d) Spring (SON). Note changes in SST scale for summer/autumn $(\mathbf{a}, \mathbf{b})$ and winter/spring $(\mathbf{c}, \mathbf{d})$. Vector data have been subsampled every two grid point to increase readability. SST data originated from multi-sensor L3S foundation SST product.

Autumn months indicated the strengthening of the LC between summer and winter (Figures $4 \mathrm{~b}$, $5 \mathrm{~b}$ and $6 \mathrm{~b}$ ). The currents during 2015 autumn were stronger when compared to 2016 and 2017. The spring months represented weakening of the LC from winter to summer (Figures $4 d, 5 d$ and $6 d$ ) and the currents during 2017 spring were stronger when compared to 2015 and 2016. The autumn and spring patterns indicated the presence of anti-clockwise eddies over the Perth canyon (approximately $32^{\circ}$ S) e.g., spring 2015 and autumn 2017. A large meander with the LC flowing in an 'S' shaped pattern was evident during spring 2017 (Figure 6d).

It is well documented that LC is weaker during El Niño events and stronger during La Niña events [11,14]. HFR data, presented here, were collected during the strong El Niño event of 2015-2016 and thus represented weaker LC conditions. Interestingly, there were differences in the cross-shelf current profiles where at latitude $31^{\circ} \mathrm{S}$ the annual mean currents recorded in 2017 were almost double the magnitude of 2015 with maximum intensity further offshore (Figure 8a). In contrast, at latitudes $31.7^{\circ} \mathrm{S}$ and $32.0^{\circ} \mathrm{S}$ there was not a large difference between the years with the maximum currents recorded in 2016 (Figure 8b,c). This could be due to the inflow from the southern South Indian Counter 
Current into the LC that occurs around $32^{\circ} \mathrm{S}$, as well as other factors such as eddy activity or other larger scale features outside the HFR domain.
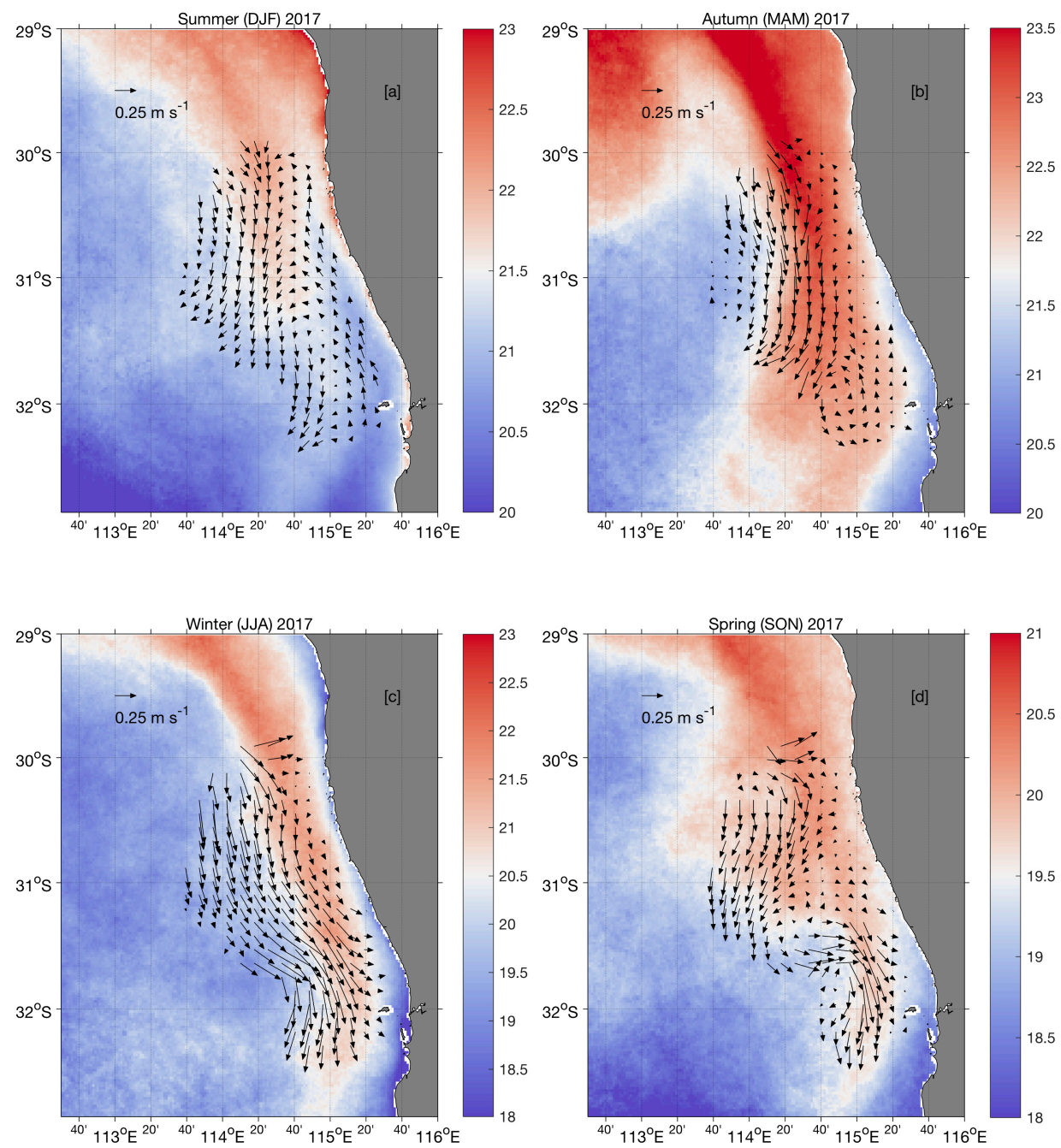

Figure 6. Seasonally-averaged HFR and SST data for 2017: (a) Summer (DJF); (b) Autumn (MAM); (c) Winter (JJA); (d) Spring (SON). Note changes in SST scale for summer/autumn (a,b) and winter/spring $(\mathbf{c}, \mathbf{d})$. Vector data have been subsampled every two grid point to increase readability. SST data originated from multi-sensor L3S foundation SST product.
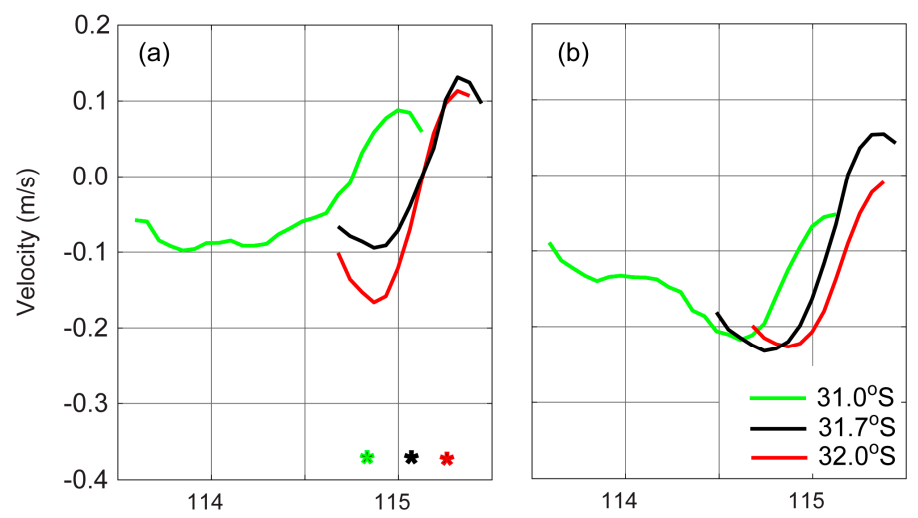

Figure 7. Mean cross-shelf profiles of HFR velocity at three different latitudes: at $31^{\circ} \mathrm{S}$ (green); $31.7^{\circ} \mathrm{S}$ (black); and, $32^{\circ} \mathrm{S}$ (red). Panel (a) refers to summer. Panel (b) refers to winter. The asterisks denote the locations of the $200 \mathrm{~m}$ depth contour. Units for the $x$-axis are ${ }^{\circ} \mathrm{E}$. 


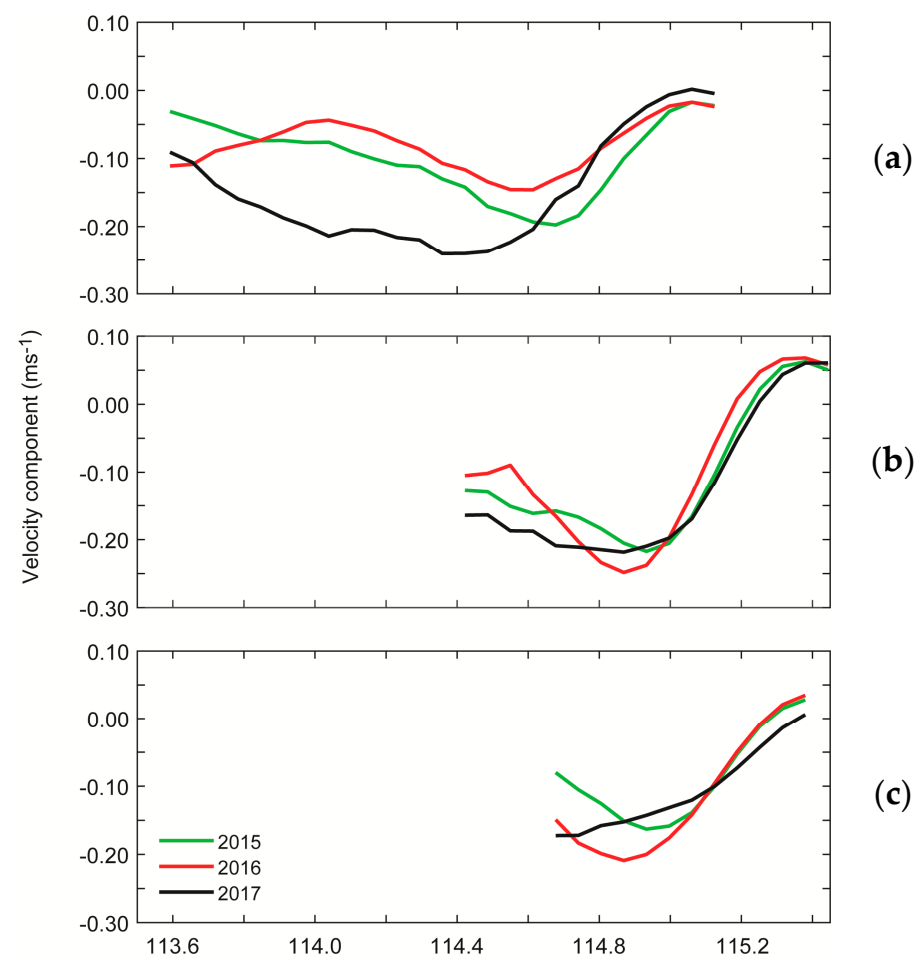

Figure 8. Mean cross-shelf profiles of HFR velocity for 2015, 2016 and 2017 at (a) $31^{\circ}$ S; (b) $31.7^{\circ}$ S; and, (c) $32^{\circ} \mathrm{S}$. Units for the $x$-axis are ${ }^{\circ} \mathrm{E}$.

\subsection{Frequency Domain Analyses}

Within the HFR domain, rotary spectra of hourly current vectors indicated common features that included energetic low-frequency components, well-defined peaks in the inertial band, (the inertial period ranged between $21 \mathrm{~h} 45 \mathrm{~m}$ and $24 \mathrm{~h} 17 \mathrm{~m}$ within the HFR domain), diurnal frequency band ( $\mathrm{K}_{1}$ and $S_{1}$ tidal constituents or wind), and limited energy within the semidiurnal tidal frequency band $\left(\mathrm{M}_{2}\right.$, $\mathrm{S}_{2}$ ). These characteristics are highlighted in the spectra (Figure 9) at the shelf break in the Turquoise coast (location 'A' in Figure 2) and the Rottnest shelf (location 'B' in Figure 2). The points A and B were selected based on their data return (in excess of $90 \%$ over the analysis period at both locations), to minimize the effects of gaps and data interpolation.

Both systems yielded similar spectral energy level at lower frequencies. However, there were differences in both the high and low frequency tails of the spectra (Figure 9): (1) at higher frequencies, SeaSonde currents contained significantly higher noise levels than that for WERA data (Figure 9a); (2) at the low-frequency bands, both SeaSonde and WERA spectra showed a predominant counterclockwise (CCW) component over the clockwise (CW) spectrum (Figure 9b) although the difference between the CCW and CW peaks were larger for SeaSonde data; and, (3) at the diurnal frequency band, the CCW spectral component was more energetic in the WERA currents and exhibited a stronger polarization ( $C R=0.98$ at a $24 \mathrm{~h}$ period) than SeaSonde data $(C R=0.86$ at a $24 \mathrm{~h}$ period) over a broader frequency range (Figure 9c). Different variance levels within the $\mathrm{CW}$ and $\mathrm{CCW}$ spectra and the corresponding rotary coefficients (CR) at point locations (A and B, Figure 2) implied dominance of quasi-circular motions within the diurnal-inertial frequency band (Figure $9 \mathrm{~b}$ ).

Similar features were observed along two zonal (East-West), cross-shore transects centered at $30^{\circ} 48^{\prime} \mathrm{S}$ (Figure 10a) and $32^{\circ} \mathrm{S}$ (Figure 10b), respectively. A different behavior between the two transects can be identified in the semidiurnal tidal frequency band, with CW variance increasing (decreasing) in the offshore direction at $30^{\circ} 48^{\prime} \mathrm{S}\left(32^{\circ} \mathrm{S}\right.$; Figure $\left.10 \mathrm{a}, \mathrm{b}\right)$. Polarization at this frequency band was negative $(\mathrm{CW})$ for both transects but changed to positive (CCW) at higher range ( $>60 \mathrm{~km}$ offshore). 

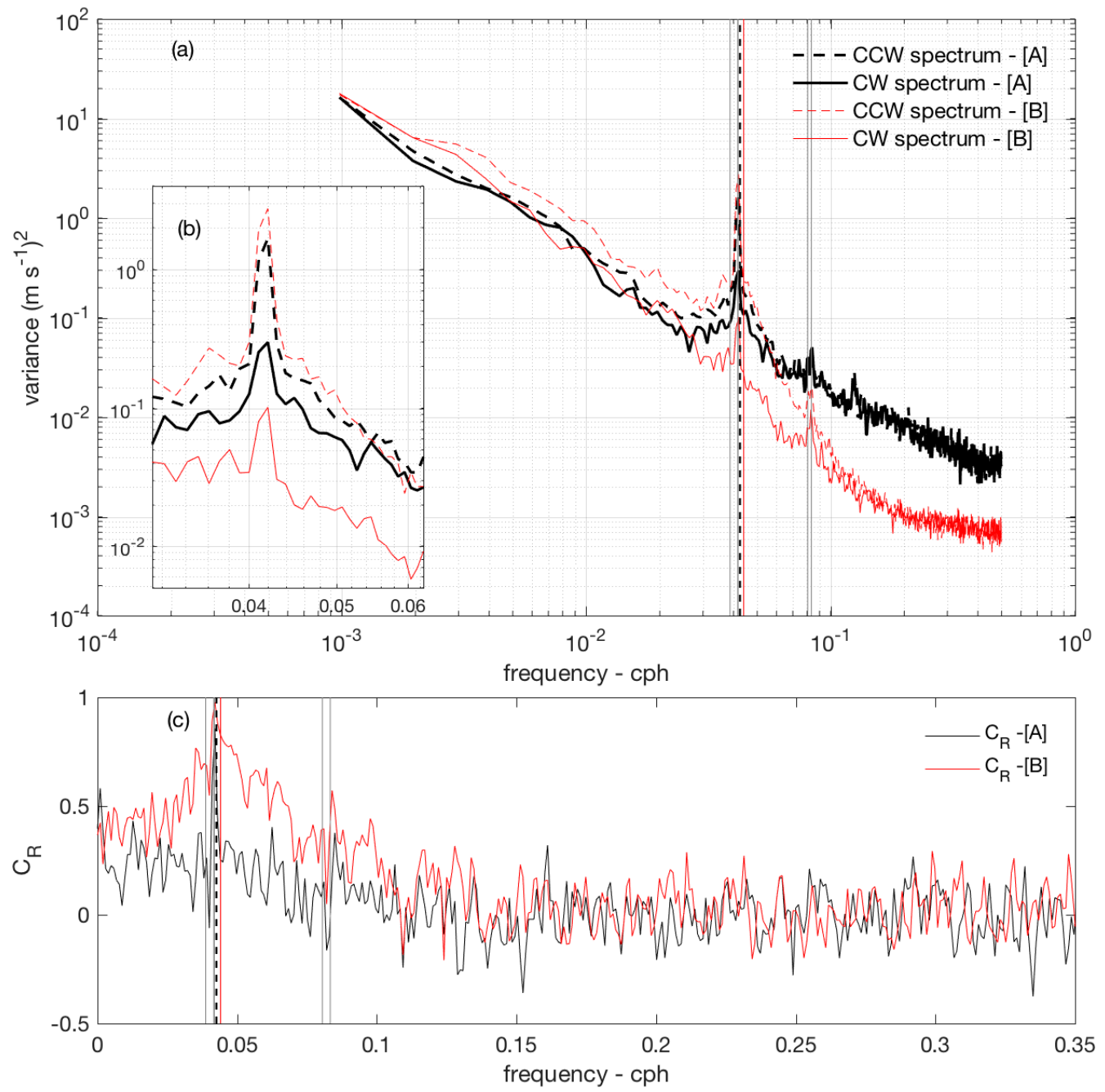

Figure 9. (a) Rotary power spectra of hourly surface currents at locations A (Seasonde) and B (WERA) (Figure 2) within the HFR domain showing the dominant spectral features in the region. Vertical lines identify the semidiurnal and diurnal frequency bands (thin grey lines), respectively; and, the inertial frequency at the two locations. (b) Same as (a), but for the diurnal frequency band. (c) Rotary coefficients $\left(C_{R}\right)$ spectra derived from for (a). Units are $\mathrm{m}^{2} \mathrm{~s}^{-2} \mathrm{cph}^{-1}$ and cycles per hour (cph) for rotary spectra and frequency axis; $C_{R}$ is dimensionless.
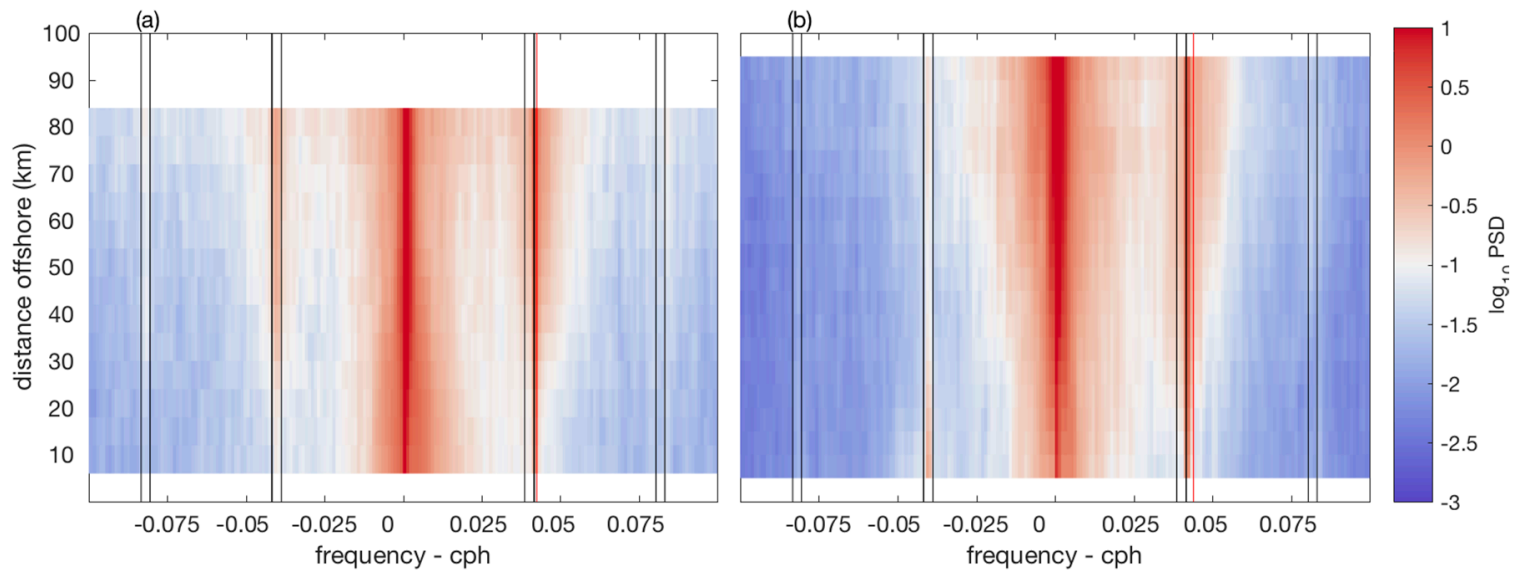

Figure 10. Cont. 

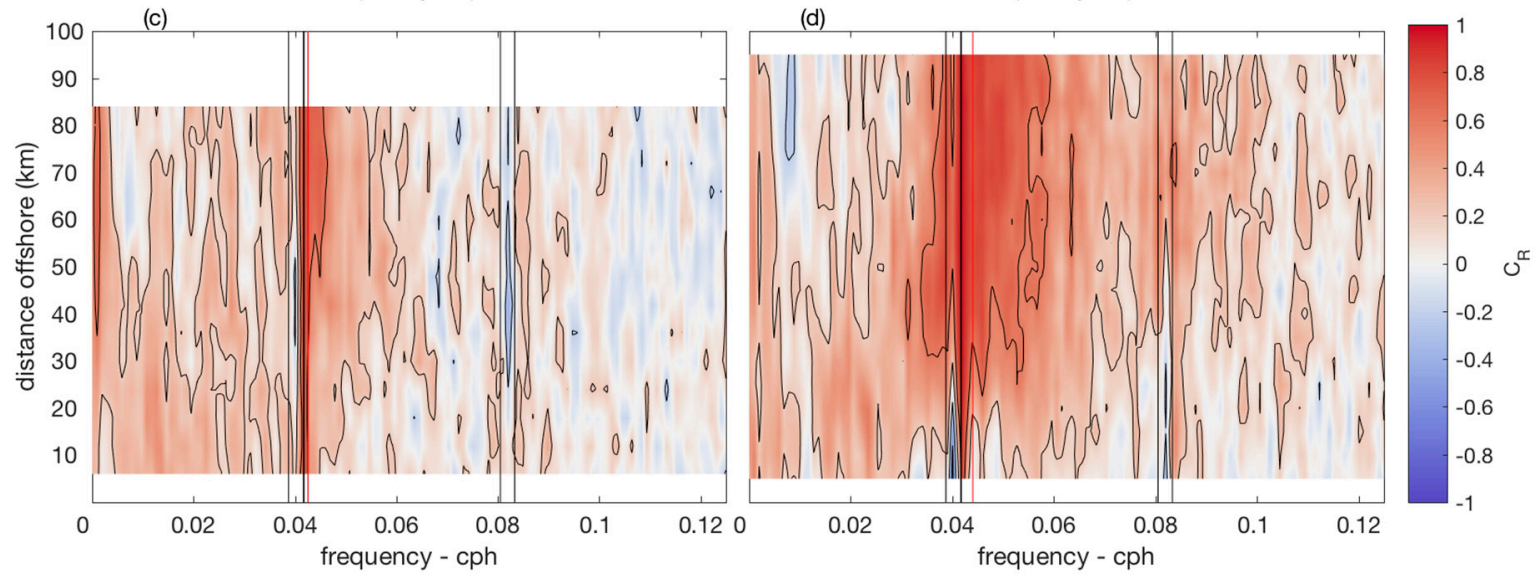

Figure 10. (a) Rotary power and rotary coefficient $\left(C_{R}\right)$ spectra of hourly surface currents along two zonal (offshore) transects at $30^{\circ} 48^{\prime} \mathrm{S}(\mathbf{a}, \mathbf{c})$; and, $32^{\circ} \mathrm{S}(\mathbf{b}, \mathbf{d})$. Vertical lines mark the semidiurnal, diurnal and inertial frequency bands at the two latitudes. Units are $\mathrm{m}^{2} \mathrm{~s}^{-2} \mathrm{cph}^{-1}$ and cycles per hour (cph) for rotary spectra and frequency axis; $\mathrm{C}_{\mathrm{R}}$ is dimensionless.

Variance levels of the currents increased both southwards and offshore, particularly within the low- and diurnal- frequency bands, with a distinct discontinuity around 30-40 km from the coast, approximately at the location of the $200 \mathrm{~m}$ depth contour (e.g., shelf break, Figure 2), indicating spatial distribution of near-inertial and diurnal variance and the low-frequency band (Figure 11). Here, the near inertial to diurnal band spans $[0.038,0.046] \mathrm{cph}$, corresponded to periods in the range [21 $\mathrm{h} 44 \mathrm{~m}$ $20.8 \mathrm{~s}, 26 \mathrm{~h} 18 \mathrm{~m} 56.8 \mathrm{~s}$ ]. The study region experiences strong diurnal-inertial resonance due to strong diurnal sea breezes and the critical latitude that generate near-inertial waves that extend to depths $>200 \mathrm{~m}$ [4]. Higher variance in deeper water (Figure 11a), therefore, reflect that the diurnal-inertial resonance being more effective in deeper water (see also [4]). The low-frequency band was defined as frequencies below $0.0088 \mathrm{cph}$ (periods longer than 4 days) and the distribution of variance indicated a band of higher values between the $200 \mathrm{~m}$ and $3000 \mathrm{~m}$ depth contours and is representative of the LC variability (Figure 11b).
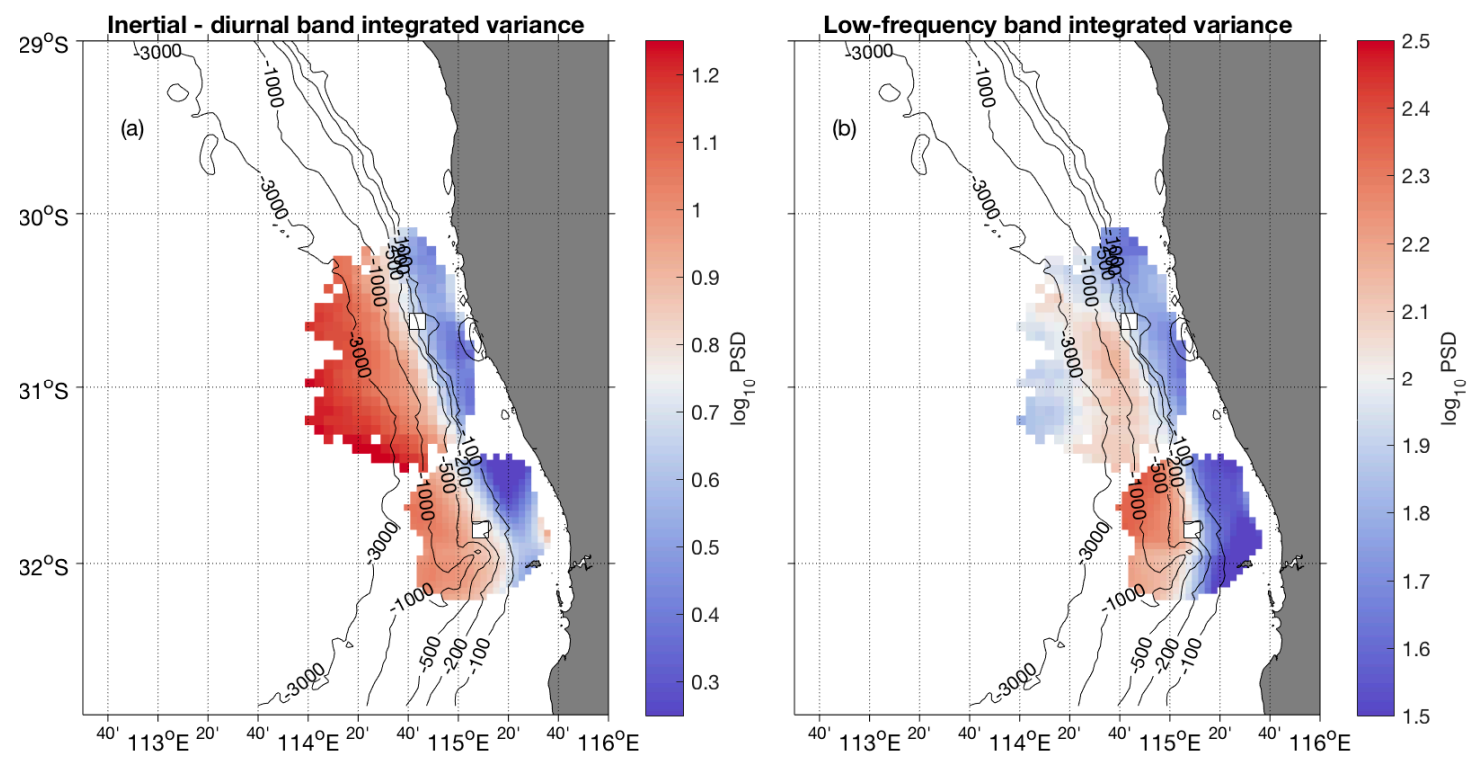

Figure 11. Spatial distribution of band-integrated current variance for (a) diurnal-inertial, corresponding to periods in the range [ $21 \mathrm{~h} 44 \mathrm{~m} 20.8 \mathrm{~s}, 26 \mathrm{~h} 18 \mathrm{~m} 56.8 \mathrm{~s}$ ]; and, (b) low-frequency (periods longer than 4 days). Note the discontinuity along the $200 \mathrm{~m}$ isobath, separating the shelf break and the deep-water regions. Units for band-integrated variance is $\log _{10}\left(\mathrm{~m}^{2} \mathrm{~s}^{-2} \mathrm{cph}^{-1}\right)$. 
Tidal currents were generally negligible, consistent with microtidal conditions in this region. Semidiurnal tides and diurnal tides represented $4 \%-10 \%$ of the total variance, with typical amplitudes that barely exceeded $0.02 \mathrm{~ms}^{-1}$ for semidiurnal constituents within the HFR coverage. Amplitudes of diurnal constituents were generally larger but they most likely reflected contamination from the strong wind-driven currents in this frequency band rather than being 'true' tidal oscillations.

\subsection{Eddy Statistics}

The LC is associated with an energetic meso-scale eddy field with maximum eddy diameters $>200 \mathrm{~km}$. However, the HFR coverage was limited to examining the sub-mesoscale (eddies with diameter $<50 \mathrm{~km}$ ). The automated eddy identification method revealed $\sim 300$ eddies with at least 1-day persistence over the period 2015-2017. There was a prevalence of counterclockwise-rotating (CCW, 177 cases) over clockwise-rotating eddies (CW, 120 cases). Eddies appeared to persist at the same location for extended periods, with typical drift distance of $\sim 10 \mathrm{~km}$ around their center; however, in some cases they were advected with the mean flow and travelled in a southwards direction with speeds up to $8 \mathrm{~km} /$ day. Their occurrence was limited to deeper water; offshore $200 \mathrm{~m}$ depth contour (Figure 12a). There were two main regions for the aggregation of eddies (Figure 12a): (1) between latitudes $30^{\circ} \mathrm{S}$ and $31.5^{\circ} \mathrm{S}$ where larger (50-60 km diameter; Figure $12 \mathrm{~b}$ ), CCW eddies were prevalent. Here, the eddies were spread over a wider region; and, (2) offshore the Rottnest island, associated with the Perth canyon (Figure 2), where both isolated or paired CW and CCW eddies were observed. The Perth canyon region was where the most persistent eddies were found concentrated in a smaller region. This is most likely due to the topographic effect of the canyon and the horizontal shear associated with the LC and the CC.

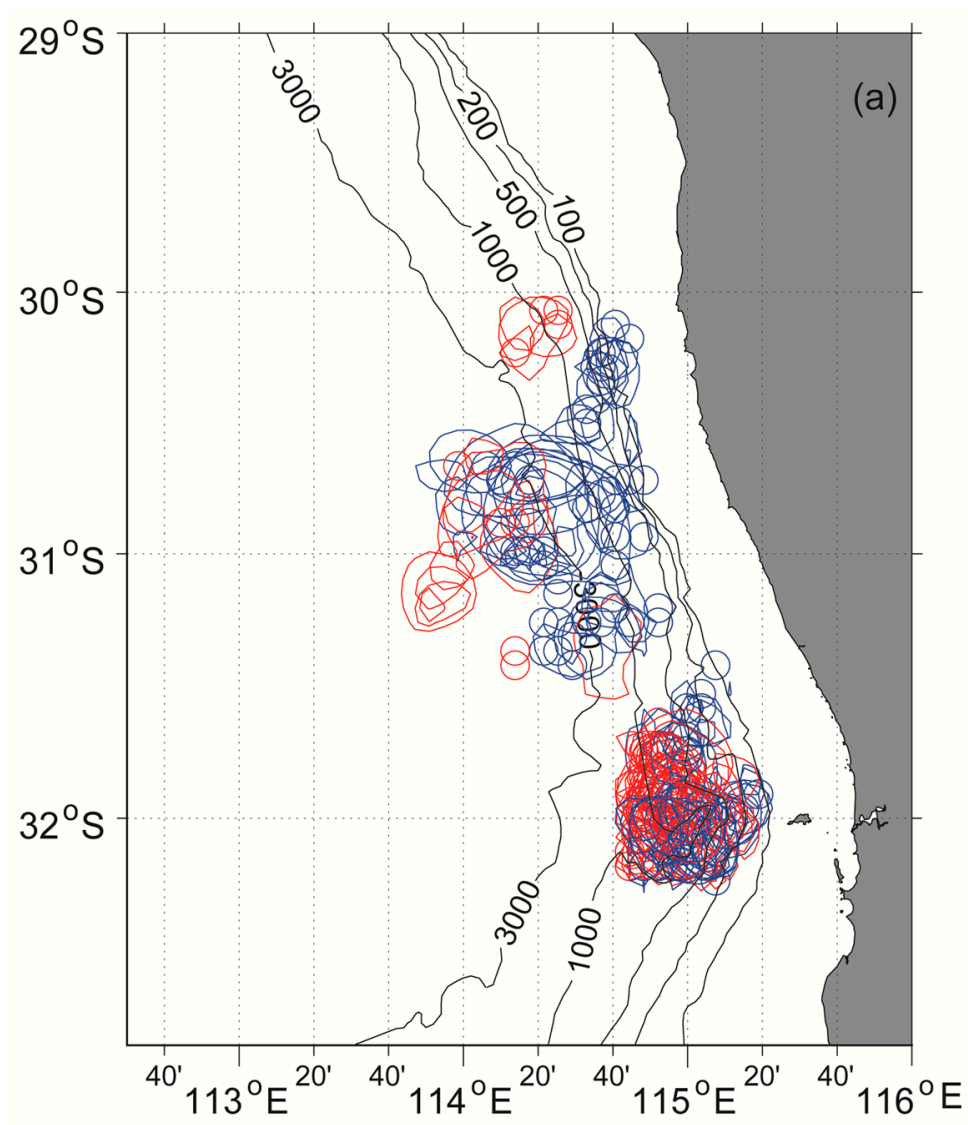

Figure 12. Cont. 


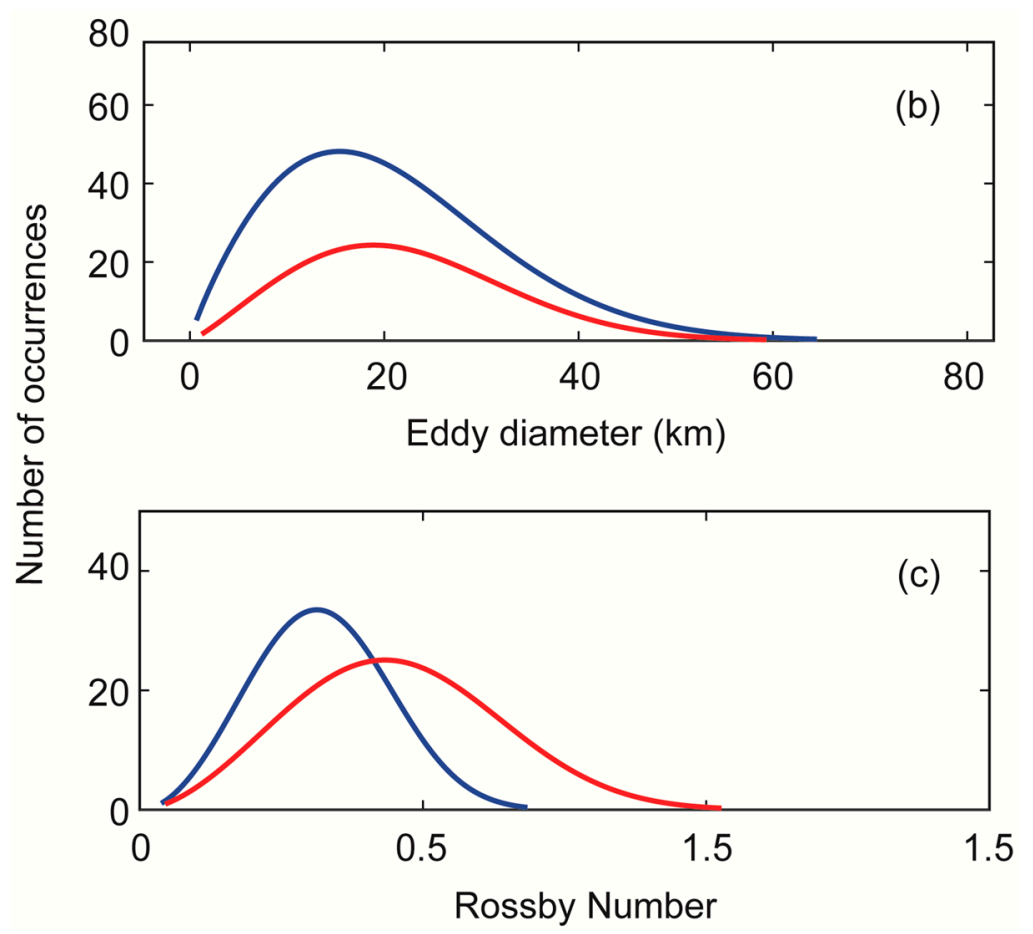

Figure 12. (a) Shapes and locations of persistent (lifespan longer than 1 day) eddies along the study region; (b) probability density distribution (pdf) curves for eddy diameters $(\mathrm{km})$; (c) probability density distribution (pdf) curves for Rossby number $\left(R_{0}\right.$; Equation (8)). Blue and red curves represent counterclockwise (CCW) and clockwise (CW) eddies.

Overall, there were 50\% more CCW eddies compared to CW with eddies with diameter 15-25 km being the most prevalent (Figure 12b). Maximum eddy diameters were up to $60 \mathrm{~km}$. The Rossby numbers $\left(R_{o}\right)$ were up to 1.5 (mean value $R_{o}=0.46$ ) for CW eddies (Figure 12c), and to $R_{o}=0.64$ for CCW eddies (mean value: $R_{o}=0.32$ ).

Time series of monthly number of days with eddies over the period January 2015 to September 2017 highlighted the seasonal and inter-annual variability (Figure 13). It should be noted that the $y$-axis in Figure 13 does not represent the number of unique eddies but rather number of days in each month ('eddy-days') where an eddy was present. For example, October 2015 indicates $>20$ days of CW eddy activity in the southern region. This was due to a single eddy that persisted for most of this month that also dominated the seasonal currents (see Figure 4d). However, even neglecting October 2015 it is obvious that 2015 had more eddies compared to 2016 and 2017. In the northern region (north of $31.5^{\circ} \mathrm{S}$ ) there were more days with CCW eddies compared to CW eddies (Figure 13b). There was also only a small month-to-month variability in the northern region (except for the second half of 2016 where there only a few 'eddy-days'). In contrast in the southern region, there was a quasi-seasonal signal with fewer 'eddy-days' during the summer (Figure 13c). 


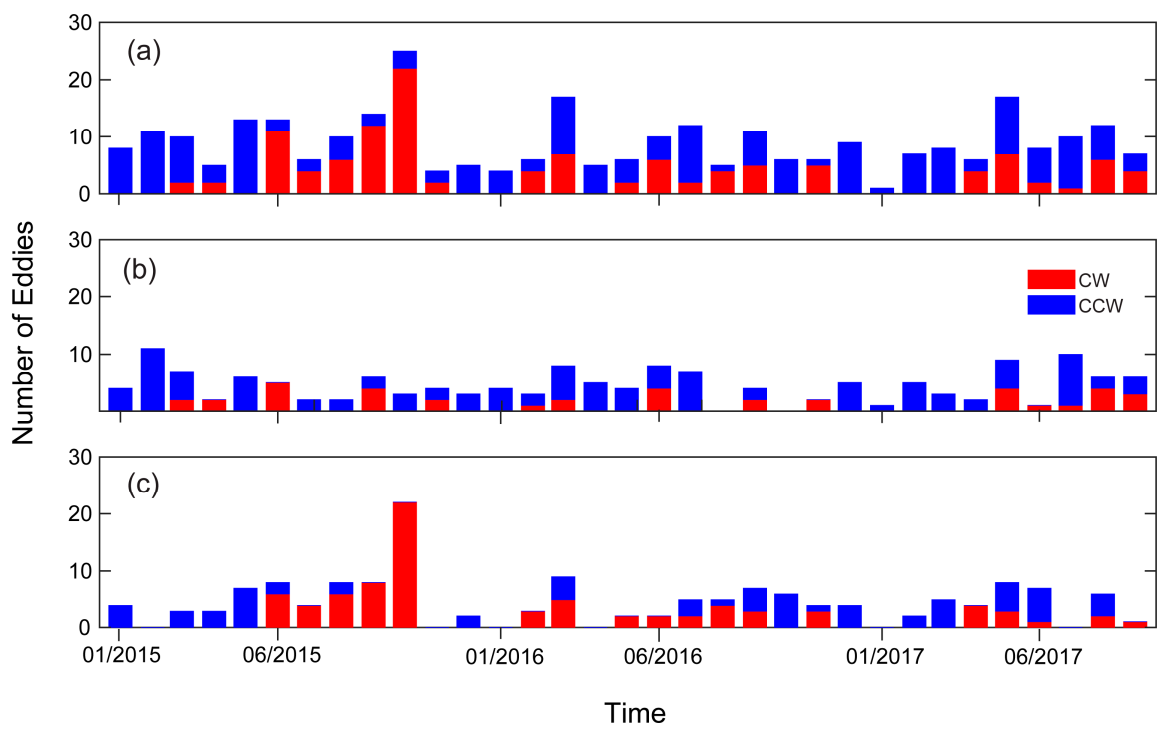

Figure 13. Time series of monthly number of days with eddies over the period January 2015 to September 2017: (a) total for the study region; (b) for the region north of north of $31.5^{\circ} \mathrm{S}$; and (c) for the region south of $31.5^{\circ} \mathrm{S}$. Blue and red bars represent counterclockwise $(\mathrm{CCW})$ and clockwise $(\mathrm{CW})$ eddies respectively.

\section{Discussions}

Ocean current measurement using HFR is well established globally over more than three decades and is one of the few techniques that provide near-real time synoptic surface currents in the coastal ocean [24,27]. Currently, two HFR systems are available commercially: SeaSonde by Codar Ocean Sensors (USA) and the WERA by Helzel MessTechnik (Germany). Although they both use HFR signals and Bragg scattering as the fundamental basis for current measurements, they use contrasting methods to estimate the surface currents. The SeaSonde system uses a direction-finding technique whilst the WERA uses a phased-array system. Although these systems are deployed at many locations [24] globally, the West Australian coast is the only region in which the two different systems are co-located and provides data along a $270 \mathrm{~km}$ of the coastline (Figure 2). The systems operate at different frequencies and resolutions: the SeaSonde at $4.463 \mathrm{MHz}$ and $6 \mathrm{~km}$ resolution with WERA at $9.335 \mathrm{MHz}$ and $4 \mathrm{~km}$. It was previously shown that data from the two major HFR genres do map accurately the observed variability of the ocean currents $[33,38]$, and that data from the two platforms can be successfully merged into a combined product. Here, we show that the combined data sets, especially at the boundaries of the two domains, have the potential to greatly increase the capabilities of coastal observing networks, in general, and along the southwestern Western Australia (SWWA) coastal region, in particular. Previous research used WERA HFR data to focus on the smaller domain in the Rottnest Shelf $[4,5]$, and neglected the area to the North, which has proven to be important for the mesoscale eddy field. The merged SeaSonde-WERA surface current data, mapped onto a $6 \mathrm{~km}$ grid, provided robust and consistent current measurements with negligible differences at the diurnal, seasonal and inter-annual time scales. Here we used a three-year record to document unreported features in the SWWA region, and plan to extend the data set to the time period 2010-2019. This data set can be used for a variety of purposes, such as calibration and validation of ocean circulation models, characterization of long-term trends, and in support of fishery management.

There was seamless transition between the two systems as evidenced by the mean (Figure 2), seasonal currents (Figures 4-6) and the variance (Figure 11). However, there were differences between the two systems due to their local configuration: the maximum horizontal ranges were $170 \mathrm{~km}$ and $105 \mathrm{~km}$ for the SeaSonde and WERA systems, respectively. This was due to the operating frequencies and grid resolution (see above). There were also differences in both the high- and low-frequency tails of 
the spectra from each system with SeaSonde currents having higher noise levels at higher frequencies whilst at the diurnal frequency band, the CCW spectral component was more energetic in the WERA currents (Figure 9).

The merged SeaSonde-WERA surface current data over the study period (January 2015 to September 2017) reflected the two major current systems in the region: Leeuwin (LC) and Capes (CC) Currents with the latter present mainly during the summer months. The southward flowing LC was associated with warmer water and was located offshore of the $200 \mathrm{~m}$ contour (Figure 2). Inshore of the $100 \mathrm{~m}$ depth contour, the currents were more variable. The northward flowing CC was present in the summer months, inshore of the LC, and was associated with colder water. The LC and CC systems are well documented along this region of the coast and the HFR data accurately reflected their presence and variability $[1,7,8,11,12]$. The 'core' of the LC was generally located offshore of the $200 \mathrm{~m}$ contour with the maximum velocity increasing from $31^{\circ} \mathrm{S}$ to $32^{\circ} \mathrm{S}$ most likely due to inflow from the South Indian Counter Current (SICC). This is consistent with the long-term numerical simulations [3] that indicated inflow from the southern arm of the SICC into the LC at around $32^{\circ} \mathrm{S}$ (see also $[43,44]$ ). The seasonal variability of the LC was well captured by the HFR data with higher currents (mean speeds up to $0.50 \mathrm{~ms}^{-1}$ ), during the winter months whilst weaker currents were present during the summer consistent with previous studies. In general, the LC was stronger during autumn/winter and weaker during spring/summer. The CC was mainly a summer feature with strong horizontal gradients at the interface between the southward flowing LC and the northwards flowing CC (see also [8]).

The study period coincided with the 2015-2016 strong El Niño event and represented conditions when the LC was weaker [11,14]. Nevertheless, there were inter-annual differences with the maximum currents recorded in 2017 almost double that recorded in 2015 (Figure 8a) as the system was adjusting to neutral ENSO conditions in 2017.

The study region has many processes that contribute to diurnal variability that include tides, inertial oscillations and sea breezes. Although the $\mathrm{K}_{1}$ and $\mathrm{O}_{1}$ diurnal tidal constituents dominate the tidal signal [45], analysis of the HFR data indicated that the tidal currents were generally negligible representing $<10 \%$ of the total variance. The study region experiences one of the strongest and persistent diurnal coastal land sea breeze (LSB) systems globally [3]. The inertial period over the HFR coverage region varies between $21 \mathrm{~h} 45 \mathrm{~m}$ and $24 \mathrm{~h} 17 \mathrm{~m}$. When the period of local wind forcing is close to the local inertial period as is the case in the study region, a resonance condition occurs. These resonant wind-current responses have been addressed in a variety of field and theoretical studies and have been shown to enhance the upper ocean velocity field and vertical mixing [4,46]. Using HFR and oceanographic mooring data, [4] documented the presence of near-inertial waves in the study region that were generated through diurnal-inertial resonance. During the austral summer, when southerly winds and the LSB system dominated the wind regime, strong counterclockwise diurnal motions with surface amplitudes $>0.3 \mathrm{~ms}^{-1}$, penetrated to $300 \mathrm{~m}$ depth with diurnal vertical isotherm fluctuations up to $60 \mathrm{~m}$ with the strongest response in water depths $>200 \mathrm{~m}$ [4]. The HFR data indicated strong CCW oscillations throughout the study region (Figure 10) with higher variance at the diurnal band in the deeper water $(>200 \mathrm{~m}$ ) consistent with the results presented by [4].

Eastern margins of ocean basins consist of large scale upwelling and equatorward flow except off the West Australian coast where the Leeuwin Current (LC) transports warmer water poleward. The LC is present due to the Indonesian Throughflow that transports water between the Pacific and Indian oceans through the Indonesian Archipelago. The LC is associated with high eddy kinetic energy that is much higher than that of other eastern boundary currents [7]. The highest eddy kinetic energy $\left(>600 \mathrm{~cm}^{2} \mathrm{~s}^{-2}\right)$ occurs offshore of the main current flow ( $200 \mathrm{~m}$ depth contour) between 28.75 and $32^{\circ} \mathrm{S}$ (Figure 12a). The LC supports a highly energetic eddy field from the sub-mesoscale to mesoscale with eddy diameters ranging from $<20 \mathrm{~km}$ to $>200 \mathrm{~m}$ [18]. Fang and Morrow [6], using altimeter data, found that majority of the mesoscale eddies were generated between $28^{\circ}$ and $31^{\circ} \mathrm{S}$ and propagated into the interior of the Indian Ocean. Over a 6 year period, [6] found that 3-9 large eddies were spawned annually. These mesoscale eddies have diameters $>100 \mathrm{~km}$ and were not wholly identified in the HFR 
data. However, there was evidence for the presence of these eddies, during the winter months, where part of the eddy was present in the HFR data (Figures 4c, 5c and 6c). HFR data, together with the automated eddy detection algorithm, were able to identify CW and CCW sub-mesoscale eddies with diameters up to $60 \mathrm{~km}$ with the majority in the range 10-20 km (Figure 12b). There were $50 \%$ more CCW eddies compared to CW eddies. The 177 eddies identified by the automated eddy detection algorithm had Rossby numbers $\left(R_{0}\right)$ of order 1 confirming that these eddy features were part of the sub-mesoscale motions. There were two main regions of eddy presence, separated to the north and south of $31.5^{\circ} \mathrm{S}$. The northern region was dominated by CCW eddies and occurred throughout the year. In contrast, the southern region was dominated by $\mathrm{CW}$ eddies and was subject to seasonal variability with lower numbers during the summer months (Figure 13). The differences in the two regions may be explained by the flow patterns associated with the LC and interaction with topography. The LC follows that $200 \mathrm{~m}$ depth contour which is similar to the changes in the shoreline orientation. At locations where the shoreline orientation changes, the LC becomes unstable and mesoscale eddies are formed [15]. This is highlighted in Figure 1 a where two large CCW eddies are seen to be spinning off the $\mathrm{LC}$ at $27.5^{\circ} \mathrm{S}$ (eddy center at $27.5^{\circ} \mathrm{S}$ ) and $30.5^{\circ} \mathrm{S}$ (eddy center at $31.5^{\circ} \mathrm{S}$ ) respectively. The circulation around the southern eddy centered at $30.5^{\circ} \mathrm{S} 31.5^{\circ} \mathrm{S}$ follows an ' $\mathrm{S}$ ' shaped pattern and are reflected in the mean seasonal HFR currents (Figures $5 c$ and $6 c, d$ ) and shown schematically in Figure 14. Here, the LC pathway separates the CCW and CW eddies to the north and south, respectively. This is the reason for the prevalence of $\mathrm{CCW}(\mathrm{CW})$ in the north (south). In the south, the concave shape of the coastline associated with the Perth canyon (Figure 2) promotes a CW eddy as reflected in HFR currents (e.g., Figures $4 d, 5 c$ and $6 c, d$ ). However, the LC pathway changes often with the whole system shown in Figure 14 shifting to the north and thus changing the orientation of eddies at different locations.

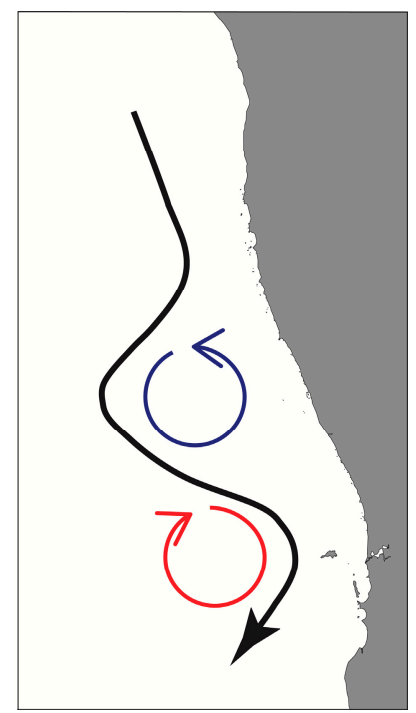

Figure 14. Schematic of the typical Leeuwin Current flow path (black line) and the generation of CCW (blue) and CW (red) vorticity and thus sub-mesoscale eddies.

\section{Conclusions}

A multi-year merged HFR data collected using SeaSonde and WERA systems, along the south-west Australia (SWWA) between $29^{\circ}-32^{\circ} \mathrm{S}$ were used to examine the ocean surface circulation at diurnal, seasonal and inter-annual time scales. The results indicated that:

- SeaSonde and WERA HFR data can be merged successfully with the potential to increase the extent of the coastal ocean under monitoring.

- The warmer poleward-flowing Leeuwin Current (LC) was the dominant feature of the circulation with a strong seasonal signal: stronger during winter and weaker during summer. The colder Capes Current (CC), located inshore of the LC, was mainly present during the summer months. 
- We observed a zonal migration of the core of the Leeuwin Current and differences in magnitude between years, however more investigation is needed to determine the driving mechanisms and long term variability.

- The contribution of tides to the circulation was small ( $<10 \%$ total variance). The energy contained in the diurnal period currents was dominant due to diurnal-inertial resonance generated strong sea breezes and inertial period at the critical latitude.

- A clear discontinuity in energy and variance distribution occurred at the shelf break that separated the continental shelf and deeper offshore regions for both diurnal and low-frequency bands reflecting reflected the diurnal-inertial resonance and the LC, respectively.

- Persistent (lifespan greater than 1 day) sub-mesoscale eddies (Rossby number O(1)) were observed at two main regions, north and south of $31.5^{\circ} \mathrm{S}$, offshore of the $200 \mathrm{~m}$ depth contour. Majority of these eddies had diameters in the range $10-20 \mathrm{~km}$ with $50 \%$ more counter clockwise rotating $(\mathrm{CCW})$ eddies compared to clockwise $(\mathrm{CW})$ rotating eddies. The northern region was dominated by CCW eddies that were present throughout the year whilst CW eddies were prevalent in the south with lower numbers during the summer months. It is planned to use the merged data set to study the generation mechanisms and the propagation of the eddies within the study area.

Author Contributions: Conceptualization, S.C., C.P., and Y.H.; methodology, S.C.; software, S.C.; formal analysis, S.C.; investigation, S.C., C.P., and Y.H.; resources, S.C. and C.P.; data curation, S.C.; writing-original draft preparation, S.C., C.P., and Y.H.; writing-review and editing, S.C., C.P., and Y.H.; visualization, S.C.; project administration, S.C.; funding acquisition, S.C. and C.P. All authors have read and agreed to the published version of the manuscript.

Funding: This research was funded by Integrated Marine Observing System IMOS-Ocean Radar-2017-2019 grant number 53000300 .

Acknowledgments: Data were sourced from the Integrated Marine Observing System (IMOS)—IMOS is supported by the Australian Government through the National Collaborative Research Infrastructure Strategy and the Super Science Initiative. Subsurface current data were collected by the IMOS-Australian National Mooring Network (ANMN) Facility. The HFR data used here were collected by the Ocean Radar Facility at the University of Western Australia. HRPT AVHRR SSTfnd retrievals are produced by the Australian Bureau of Meteorology as a contribution to the Integrated Marine Observing System-an initiative of the Australian Government being conducted as part of the National Collaborative Research Infrastructure Strategy and the Super Science Initiative. The imagery data were acquired from NOAA spacecraft by the Bureau, Australian Institute of Marine Science, Australian Commonwealth Scientific and Industrial Research Organization, Geoscience Australia, and Western Australian Satellite Technology and Applications Consortium.

Conflicts of Interest: The authors declare no conflict of interest.

\section{References}

1. Pattiaratchi, C.B.; Woo, M. The mean state of the Leeuwin Current system between North West Cape and Cape Leeuwin. J. R. Soc. West. Aust. 2009, 92, 221-241.

2. Pattiaratchi, C.B.; Hollings, B.; Woo, M.; Welhena, T. Dense shelf water formation along the south-west Australian inner shelf. Geophys. Res. Lett. 2011, 38, L10609. [CrossRef]

3. Pattiaratchi, C.B.; Hegge, B.; Gould, J.; Eliot, I. Impact of sea-breeze activity on nearshore and foreshore processes in southwestern Australia. Cont. Shelf Res. 1997, 17, 1539-1560. [CrossRef]

4. Mihanovic, H.; Pattiaratchi, C.B.; Verspecht, F. Diurnal sea breezes force near-inertial waves along Rottnest continental shelf, Southwestern Australia. J. Phys. Oceanogr. 2016, 46, 3487-3508. [CrossRef]

5. Mahjabin, T.; Pattiaratchi, C.B.; Hetzel, Y. Wind effects on dense shelf water cascades in south-west Australia. Cont. Shel. Res. 2019, 189. [CrossRef]

6. Fang, F.; Morrow, R. Evolution, movement and decay of warm-core Leeuwin Current eddies. Deep Sea Res. Part II Top. Stud. Oceanogr. 2003, 50, 2245-2261. [CrossRef]

7. Gersbach, G.H.; Pattiaratchi, C.B.; Ivey, G.N.; Cresswell, G.R. Upwelling on the south-west coast of Australia-Source of the Capes Current? Cont. Shelf Res. 1999. [CrossRef]

8. Pearce, A.; Pattiaratchi, C.B. The Capes Current: A summer countercurrent flowing past Cape Leeuwin and Cape Naturaliste, Western Australia. Cont. Shelf Res. 1998, 18, 401-421. [CrossRef] 
9. Smith, R.L.; Huyer, A.; Godfrey, J.S.; Church, J.A. The Leeuwin Current off Western Australia. J. Phys. Oceanogr. 1991, 21, 813-827. [CrossRef]

10. Feng, M.; Meyers, G.; Pearce, A.; Wijffels, S. Annual and inter-annual variations of the Leeuwin Current at 32oS. J. Geophys. Res. Oceans 2003, 108, 3355. [CrossRef]

11. Wijeratne, E.M.S.; Pattiaratchi, C.B.; Proctor, R. Estimates of surface and subsurface boundary currents transport around Australia. J. Geophys. Res. Oceans 2018, 3444-3466. [CrossRef]

12. Ridgway, K.R.; Condie, S.A. The 5500-km-long boundary flow of western and southern Australia. J. Geophys. Res. Oceans 2009, 109, C04017. [CrossRef]

13. Ridgway, K.R.; Godfrey, J.S. The source of the Leeuwin Current seasonality. J. Geophys. Res. Oceans 2015, 120, 6843-6864. [CrossRef]

14. Pattiaratchi, C.B.; Buchan, S.J. Implications of long- term climate change for the Leeuwin Current. J. R. Soc. West. Aust. 1991, 74, 133-140.

15. Pearce, A.F.; Griffiths, R.W. The mesoscale structure of the Leeuwin Current: A comparison of laboratory models and satellite imagery. J. Geophys. Res. 1991, 96, 16739. [CrossRef]

16. Waite, A.M.; Thompson, P.A.; Pesant, S.; Feng, M.; Beckley, L.E.; Domingues, C.M.; Gaughan, D.; Hanson, C.E.; Holl, C.M.; Koslow, T. The Leeuwin Current and its eddies: An introductory overview. Deep Sea Res. Part II Top. Stud. Oceanogr. 2007, 54, 789-796. [CrossRef]

17. Meuleners, M.J.; Pattiaratchi, C.B.; Ivey, G.N. Numerical modelling of the mean flow characteristics of the Leeuwin current system. Deep Sea Res. Part II Top. Stud. Oceanogr. 2007, 54, 837-858. [CrossRef]

18. Rennie, S.J.; Pattiaratchi, C.; McCauley, R.D. Eddy formation through the interaction between the Leeuwin Current, Leeuwin Undercurrent and topography. Deep Sea Rese Part II Top. Stud. Oceanogr. 2007, 54, 818-836. [CrossRef]

19. Rennie, S.J.; Pattiaratchi, C.B.; McCauley, R.D. Numerical simulation of the circulation within the Perth submarine canyon, Western Australia. Cont. Shelf Res. 2009, 29, 2020-2036. [CrossRef]

20. Rennie, S.J.; Hanson, C.E.; McCauley, R.D.; Pattiaratchi, C.B.; Burton, C.; Bannister, J.; Jenner, C.; Jenner, M.-N. Physical properties and processes in the Perth Canyon, Western Australia: Links to water column production and seasonal pygmy blue whale abundance. J. Mar. Syst. 2009, 77, 21-44. [CrossRef]

21. Wandres, M.; Wijeratne, E.M.S.; Cosoli, S.; Pattiaratchi, C.B. The effect of the Leeuwin Current on offshore surface gravity waves in southwest western Australia. J. Geophys. Res. Oceans 2017, 122, 9047-9067. [CrossRef]

22. Gallop, S.L.; Verspecht, F.; Pattiaratchi, C.B. Sea breezes drive currents on the inner continental shelf off southwest Western Australia. Ocean Dyn. 2012, 62, 569-583. [CrossRef]

23. Verspecht, F.; Pattiaratchi, C.B. On the significance of wind event frequency for particulate resuspension and light attenuation in coastal waters. Cont. Shelf Res. 2010, 30, 1971-1982. [CrossRef]

24. Roarty, H.; Cook, T.; Hazard, L.; George, D. The Global High Frequency Radar Network Front. Mar. Sci. 2019, 6, 164. [CrossRef]

25. Barrick, D.E.; Evans, M.W.; Weber, B.L. Ocean surface currents mapped by radar. Science 1977, 198, $138-144$. [CrossRef]

26. Hammond, T.M.; Pattiaratchi, C.B.; Eccles, D.; Osborne, M.J.; Nash, L.A.; Collins, M.B. Ocean Surface Current Radar (OSCR) vector measurements on the inner continental shelf. Cont. Shelf Res. 1987, 7, 411-431. [CrossRef]

27. Paduan, J.D.; Washburn, L. High-frequency radar observations of ocean surface currents. Annu. Rev. Mar. Sci. 2013, 5, 115-136. [CrossRef]

28. Lipa, B.; Barrick, D.; Whelan, C. A Quality Control Method for Broad-Beam HF Radar Current Velocity Measurements. J. Mar. Sci. Eng. 2019, 7, 112. [CrossRef]

29. Ren, L.; Miao, J.; Li, Y.; Luo, X.; Li, J.; Hartnett, M. Estimation of Coastal Currents Using a Soft Computing Method: A Case Study in Galway Bay, Ireland. J. Mar. Sci. Eng. 2019, 7, 157. [CrossRef]

30. Lorente, P.; Piedracoba, S.; Sottillo, M.G.; Alvarez-Fanjul, E. Long-Term Monitoring of the Atlantic Jet through the Strait of Gibraltar with HF Radar Observations. J. Mar. Sci. Eng. 2019, 7, 3. [CrossRef]

31. Twomey, L.J.; Waite, A.M.; Pez, V.; Pattiaratchi, C.B. Variability in nitrogen uptake and fixation in the oligotrophic waters off the south west coast of Australia. Deep Sea Res. Part II Top. Stud. Oceanogr. 2007, 54, 925-942. [CrossRef] 
32. Griffin, C.; Beggs, H.; Majewski, L. GHRSST Compliant AVHRR SST Products over the Australian Region; Version 1, Technical Report; Bureau of Meteorology: Melbourne, Australia, 2017; p. 151.

33. Cosoli, S.; Grcic, B.; de Vos, S.; Hetzel, Y. Improving Data Quality for the Australian High Frequency Ocean Radar Network through Real-Time and Delayed-Mode Quality-Control Procedures. Remote Sens. 2018, 10, 1476. [CrossRef]

34. Welch, P.D. The use of fast-Fourier transform for the estimation of power spectra: A method based on time-averaging over short, modified periodograms. IEEE Trans. Audio Electroacoust. 1967, 2,70-73. [CrossRef]

35. van Haren, H. On the polarization of oscillatory currents in the Bay of Biscay. J. Geophys. Res. 2003, $108,3290$. [CrossRef]

36. Pawlowicz, R.; Beardsley, B.; Lentz, S. Classical tidal harmonic analysis including error estimates in MATLAB using T_TIDE. Comput. Geosci. 2002, 28, 929-937. [CrossRef]

37. Cosoli, S.; Grcic, B. Quality Control Procedures for IMOS Ocean Radar Manual; Integrated Marine Observing System Version 2.0; UNESCO/IOC Project Office for IODE: Oostende, Belgium, 2019. [CrossRef]

38. Cosoli, S.; de Vos, S. Interoperability of Direction-Finding and Beam-Forming High-Frequency Radar Systems: An Example from the Australian High-Frequency Ocean Radar Network. Remote Sens. 2019, 11, 291. [CrossRef]

39. Kundu, P.K. Ekman veering observed near the ocean bottom. J. Phys. Oceanogr. 1976, 6, 238-242. [CrossRef]

40. McWilliams, J.C. A survey of submesoscale currents. Geosci. Lett. 2019, 6. [CrossRef]

41. Nencioli, F.; Dong, C.; Dickey, T.; Washburn, L.; McWilliams, J.C. A vector geometry based eddy detection algorithm and its application to a high-resolution numerical model product and high-frequency radar surface velocities in the Southern California Bight. J. Atmos. Ocean. Technol. 2010, 27, 564-579. [CrossRef]

42. Sanderson, B.G. Structure of an eddy measured with drifters. J. Geophys. Res. 1995, 100, 6761-6776. [CrossRef]

43. Menezes, V.V.; Phillips, H.E.; Vianna, M.L.; Bindoff, N.L. Interannual variability of the South Indian Countercurrent. J. Geophys. Res. (Oceans) 2016, 121, 3465-3487. [CrossRef]

44. Lambert, E.; Le Bars, D.; de Ruijter, W.P.M. The connection of the Indonesian Throughflow, South Indian Ocean Countercurrent and the Leeuwin Current. Ocean Sci. 2016, 12, 771-780. [CrossRef]

45. Pattiaratchi, C.B.; Eliot, M. Sea level variability in south-west Australia: From hours to decades. In Coastal Engineering, Proceedings of the Thirty-First International Coastal Engineering Conference, Rio de Janeiro, Brazil, 31 August-5 September 2008; Smith, J.M., Ed.; World Scientific Publishing: Singapore, 2008; pp. 1186-1198.

46. Simpson, J.H.; Hyder, P.; Rippeth, T.P. Forced oscillations near the critical latitude for diurnal-inertial resonance. J. Phys. Oceanogr. 2002, 32, 177-187. [CrossRef] 